Prepared in cooperation with the IDAHO DEPARTMENT OF WATER RESOURCES and the WASHINGTON STATE DEPARTMENT OF ECOLOGY
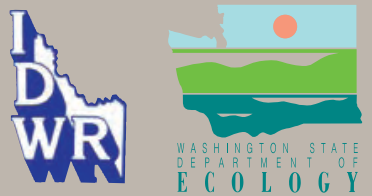

Assessment of Areal Recharge to the Spokane Valley-Rathdrum Prairie Aquifer, Spokane County, Washington, and Bonner and Kootenai Counties, Idaho

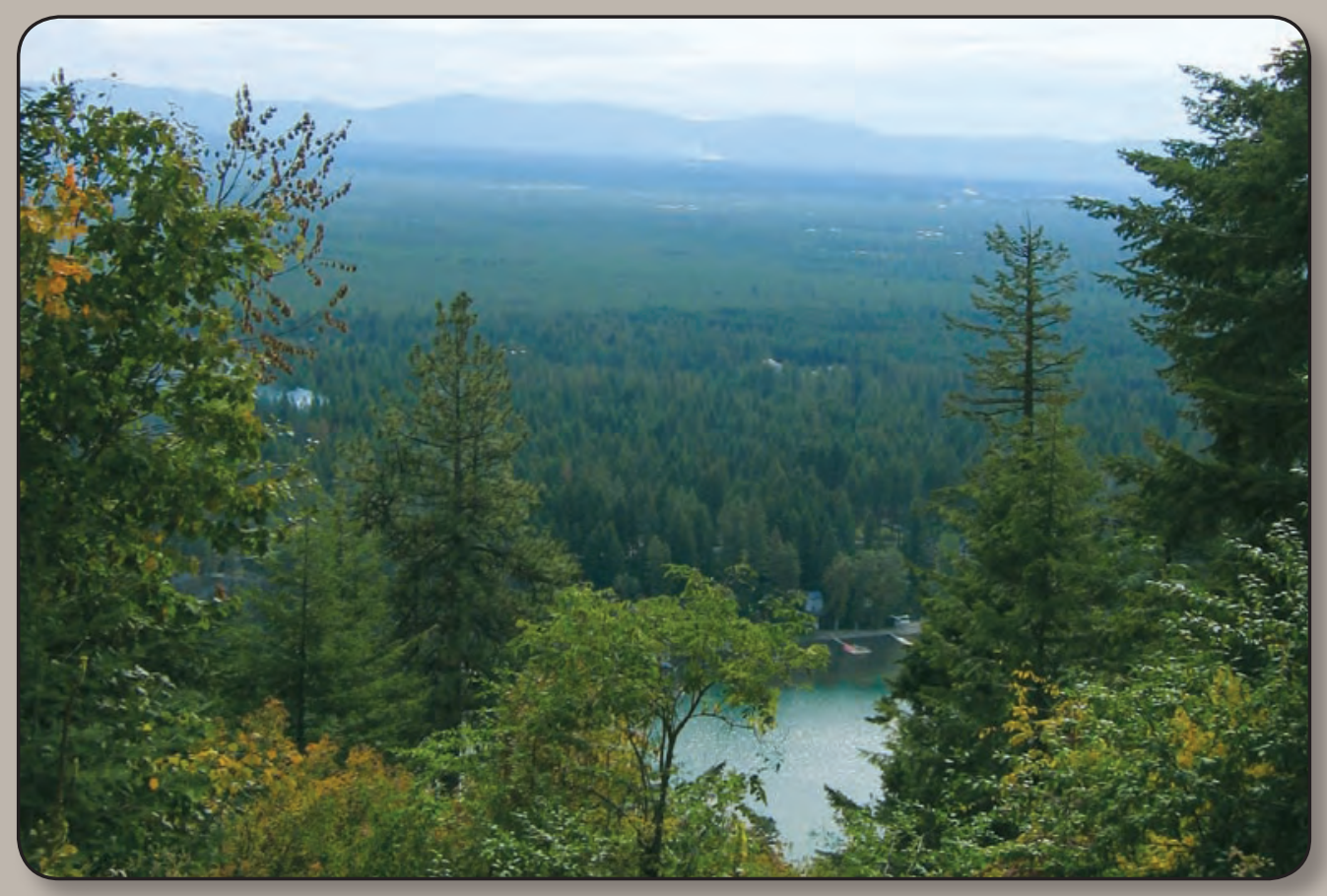

Scientific Investigations Report 2007-5038 
Cover: Photograph of the Rathdum Prairie from above Twin Lakes, Idaho.

(Photograph by James Bartolino, U.S. Geological Survey, September 23, 2004.) 


\section{Assessment of Areal Recharge to the Spokane Valley-Rathdrum Prairie aquifer, Spokane County, Washington, and Bonner and Kootenai Counties, Idaho}

By James R. Bartolino

Prepared in cooperation with the

Idaho Department of Water Resources and the

Washington State Department of Ecology

Scientific Investigations Report 2007-5038 


\section{U.S. Department of the Interior DIRK KEMPTHORNE, Secretary}

\section{U.S. Geological Survey \\ Mark D. Myers, Director}

\section{U.S. Geological Survey, Reston, Virginia: 2007}

For product and ordering information:

World Wide Web: http://www.usgs.gov/pubprod

Telephone: 1-888-ASK-USGS

For more information on the USGS--the Federal source for science about the Earth, its natural and living resources, natural hazards, and the environment:

World Wide Web: http://www.usgs.gov

Telephone: 1-888-ASK-USGS

Any use of trade, product, or firm names is for descriptive purposes only and does not imply endorsement by the U.S. Government.

Although this report is in the public domain, permission must be secured from the individual copyright owners to reproduce any copyrighted materials contained within this report.

Suggested citation:

Bartolino, J.R., 2007, Assessment of areal recharge to the Spokane Valley-Rathdrum Prairie aquifer, Spokane County, Washington, and Bonner and Kootenai Counties, Idaho: U.S. Geological Survey Scientific Investigations Report 2007$5038,38 \mathrm{p}$. 


\section{Contents}

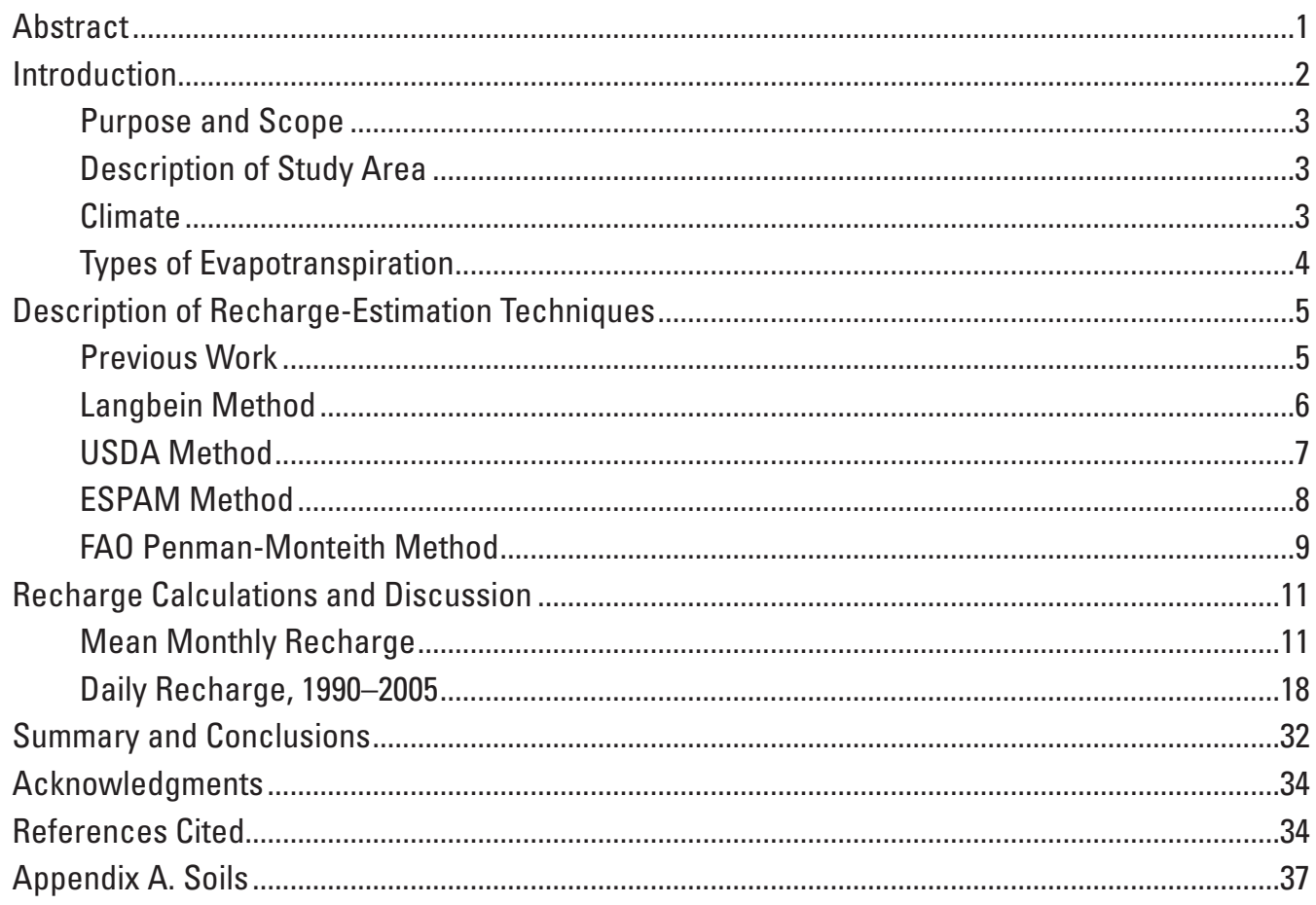

\section{Figures}

Figure 1. Map showing location of the Spokane Valley-Rathdrum Prairie aquifer and National Weather Service stations in and near the study area...

Figure 2. Graph showing mean annual precipitation and recharge calculated by various methods at six weather stations in the study area

Figure 3. Graphs showing mean monthly precipitation and recharge at each weather station, Idaho and Washington

Figure 4. Graphs showing daily values of precipitation and dual-coefficient FAO Penman-Monteith deep percolation, 1990-2005, Spokane WSO Airport, Washington

Figure 5. Graphs showing daily values of precipitation and dual-coefficient FAO Penman-Monteith deep percolation, 1990-2005, Bayview Model Basin, Idaho $\ldots 27$

Figure 6. Graphs showing daily values of precipitation and dual-coefficient FAO Penman-Monteith deep percolation, 1995-2005, Coeur D'Alene 1E, Idaho ........ 28

Figure 7. Graphs showing daily values of precipitation and dual-coefficient FAO Penman-Monteith deep percolation, 1990-2005, Newport, Washington

Figure 8. Graphs showing daily values of precipitation and dual-coefficient FAO Penman-Monteith deep percolation, 1990-2005, Priest River Experiment Station, Idaho

Figure 9. Graphs showing daily values of precipitation and dual-coefficient FAO Penman-Monteith deep percolation, 1990-2005, Sandpoint Experiment Station, Idaho

Figure 10. Graph showing comparison of previous monthly recharge rate estimates with dual-coefficient FAO Penman-Monteith recharge, 1995-2005 


\section{Tables}

Table 1. National Weather Service stations in or near the study area $\ldots \ldots \ldots \ldots \ldots \ldots \ldots$

Table 2. Summary of data from active weather stations in and near the Spokane

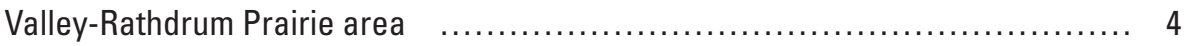

Table 3. Summary of meteorological data necessary for recharge calculations $\ldots \ldots \ldots \ldots .4$

Table 4. Mean annual precipitation at active weather stations and calculated Langbein recharge

Table 5. Mean monthly precipitation at active weather stations and U.S. Department of Agriculture recharge ....

Table 6. Mean monthly precipitation at active weather stations and calculated Eastern Snake Plain Aquifer Model recharge (thin-soil parameters)

Table 7. Mean monthly precipitation at active weather stations and calculated Eastern Snake Plain Aquifer Model recharge (thick-soil parameters)

Table 8. Mean monthly precipitation at active weather stations and calculated Eastern Snake Plain Aquifer Model recharge (lava-rock parameters)

Table 9. Mean monthly precipitation at active weather stations and single-coefficient FAO Penman-Monteith recharge, Spokane WSO Airport, Washington

Table 10. Monthly precipitation and dual-coefficient FAO Penman-Monteith recharge using daily values, 1995-2005, Spokane WSO Airport, Washington

Table 11. Monthly precipitation and dual-coefficient FAO Penman-Monteith recharge using daily values, 1995-2005, Bayview Model Basin, Idaho....

Table 12. Monthly precipitation and dual-coefficient FAO Penman-Monteith recharge using daily values, 1995-2005, Coeur D'Alene 1E, Idaho

Table 13. Monthly precipitation and dual-coefficient FAO Penman-Monteith recharge using daily values, 1995-2005, Newport, Washington

Table 14. Monthly precipitation and dual-coefficient FAO Penman-Monteith recharge using daily values, 1995-2005, Priest River Experiment Station, Idaho 25

Table 15. Monthly precipitation and dual-coefficient FAO Penman-Monteith recharge using daily values, 1995-2005, Sandpoint Experiment Station, Idaho 


\section{Conversion Factors and Datums}

Conversion Factors

\begin{tabular}{lll}
\hline \multicolumn{1}{c}{ Multiply } & \multicolumn{1}{c}{ By } & \multicolumn{1}{c}{ To obtain } \\
\hline cubic foot per second $\left(\mathrm{ft}^{3} / \mathrm{s}\right)$ & 0.02832 & cubic meter per second $\left(\mathrm{m}^{3} / \mathrm{s}\right)$ \\
foot $(\mathrm{ft})$ & 0.3048 & meter $(\mathrm{m})$ \\
foot per day $(\mathrm{ft} / \mathrm{d})$ & 0.3048 & meter per day $(\mathrm{m} / \mathrm{d})$ \\
inch $(\mathrm{in})$. & 25.4 & millimeter $(\mathrm{mm})$ \\
inch per day $(\mathrm{in} / \mathrm{d})$ & 25.4 & millimeter per day $(\mathrm{mm} / \mathrm{d})$ \\
inch per month $(\mathrm{in} / \mathrm{mo})$ & 25.4 & millimeter per day $(\mathrm{mm} / \mathrm{mo})$ \\
joule $(\mathrm{J})$ & 0.0000002 & Kilowatt hour $(\mathrm{kWh})$ \\
kilopascal $(\mathrm{kPa})$ & 0.009869 & atmosphere, standard $(\mathrm{atm})$ \\
meter per second $(\mathrm{m} / \mathrm{s})$ & 3.281 & foot per second $(\mathrm{ft} / \mathrm{s})$ \\
mile $(\mathrm{mi})$ & 1.609 & kilometer $(\mathrm{km})$ \\
square mile $\left(\mathrm{mi}^{2}\right)$ & 2.590 & square kilometer $\left(\mathrm{km}^{2}\right)$ \\
\hline
\end{tabular}

Temperature in degrees Celsius $\left({ }^{\circ} \mathrm{C}\right)$ may be converted to degrees Fahrenheit $\left({ }^{\circ} \mathrm{F}\right)$ as follows:

$$
{ }^{\circ} \mathrm{F}=\left(1.8 x^{\circ} \mathrm{C}\right)+32 \text {. }
$$

Temperature in degrees Fahrenheit $\left({ }^{\circ} \mathrm{F}\right)$ may be converted to degrees Celsius $\left({ }^{\circ} \mathrm{C}\right)$ as follows:

$$
{ }^{\circ} \mathrm{C}=\left({ }^{\circ} \mathrm{F}-32\right) / 1.8 \text {. }
$$

Datums

Vertical coordinate information is referenced to the North American Vertical Datum of 1929 (NAVD 29).

Horizontal coordinate information is referenced to the North American Datum of 1927 (NAD 27).

Altitude, as used in this report, refers to distance above the vertical datum. 
This page intentionally left blank. 


\title{
Assessment of Areal Recharge to the Spokane Valley- Rathdrum Prairie Aquifer, Spokane County, Washington, and Bonner and Kootenai Counties, Idaho
}

\author{
By James R. Bartolino
}

\section{Abstract}

A numerical flow model of the Spokane ValleyRathdrum Prairie aquifer currently (2007) being developed requires the input of values for areally-distributed recharge, a parameter that is often the most uncertain component of water budgets and ground-water flow models because it is virtually impossible to measure over large areas. Data from six active weather stations in and near the study area were used in four recharge-calculation techniques or approaches; the Langbein method, in which recharge is estimated on the basis of empirical data from other basins; a method developed by the U.S. Department of Agriculture (USDA), in which crop consumptive use and effective precipitation are first calculated and then subtracted from actual precipitation to yield an estimate of recharge; an approach developed as part of the Eastern Snake Plain Aquifer Model (ESPAM) Enhancement Project in which recharge is calculated on the basis of precipitation-recharge relations from other basins; and an approach in which reference evapotranspiration is calculated by the Food and Agriculture Organization (FAO) PenmanMonteith equation, crop consumptive use is determined (using a single or dual coefficient approach), and recharge is calculated.

Annual recharge calculated by the Langbein method for the six weather stations was 4 percent of annual mean precipitation, yielding the lowest values of the methods discussed in this report, however, the Langbein method can be only applied to annual time periods. Mean monthly recharge calculated by the USDA method ranged from 53 to 73 percent of mean monthly precipitation. Mean annual recharge ranged from 64 to 69 percent of mean annual precipitation. Separate mean monthly recharge calculations were made with the ESPAM method using initial input parameters to represent thin-soil, thick-soil, and lava-rock conditions. The lavarock parameters yielded the highest recharge values and the thick-soil parameters the lowest. For thin-soil parameters, calculated monthly recharge ranged from 10 to 29 percent of mean monthly precipitation and annual recharge ranged from 16 to 23 percent of mean annual precipitation. For thick-soil parameters, calculated monthly recharge ranged from 1 to 5 percent of mean monthly precipitation and mean annual recharge ranged from 2 to 4 percent of mean annual precipitation. For lava-rock parameters, calculated mean monthly recharge ranged from 37 to 57 percent of mean monthly precipitation and mean annual recharge ranged from 45 to 52 percent of mean annual precipitation.

Single-coefficient (crop coefficient) FAO PenmanMonteith mean monthly recharge values were calculated for Spokane Weather Service Office (WSO) Airport, the only station for which the necessary meteorological data were available. Grass-referenced values of mean monthly recharge ranged from 0 to 81 percent of mean monthly precipitation and mean annual recharge was 21 percent of mean annual precipitation; alfalfa-referenced values of mean monthly recharge ranged from 0 to 85 percent of mean monthly precipitation and mean annual recharge was 24 percent of mean annual precipitation. Single-coefficient FAO PenmanMonteith calculations yielded a mean monthly recharge of zero during the eight warmest and driest months of the year (March-October).

In order to refine the mean monthly recharge estimates, dual-coefficient (basal crop and soil evaporation coefficients) FAO Penman-Monteith dual-crop evapotranspiration and deep-percolation calculations were applied to daily values from the Spokane WSO Airport for January 1990 through December 2005. The resultant monthly totals display a temporal variability that is absent from the mean monthly values and demonstrate that the daily amount and timing of precipitation dramatically affect calculated recharge. The dual-coefficient FAO Penman-Monteith calculations were made for the remaining five stations using wind-speed values for Spokane WSO Airport and other assumptions regarding missing data. For the six stations, monthly recharge (totaled from daily values, 1990-2005) ranged from 0 to 94 percent of monthly precipitation.

Without a priori knowledge of probable values of areal recharge, choosing between values of recharge calculated by different methods is a challenging decision. Thus, the larger context provided by water budgets and ground-water flow model calibration is crucial in determining reasonable values. 


\section{Introduction}

The approximately $370 \mathrm{mi}^{2}$ Spokane Valley-Rathdrum Prairie (SVRP) aquifer straddles the Idaho-Washington state line northeast of the City of Spokane (fig. 1). Because the aquifer serves as the sole source of drinking water for more than 400,000 people and the area is experiencing rapid population growth, a better understanding of the aquifer characteristics and its interaction with the Spokane River is necessary to guide the development and management of the resource. To this end, a multi-year study began in 2003 to gather data necessary to construct a ground-water flow model of the SVRP aquifer that both states could use to evaluate potential water-development and management alternatives.
Currently (2007), a ground-water-flow model that simulates ground-water/surface-water interaction is under construction by a joint team from the Idaho Department of Water Resources, University of Idaho, Washington State University, and the U.S. Geological Survey. This model requires values for areally distributed recharge from precipitation, but such values are commonly the most uncertain components of water budgets and ground-water flow models because it is virtually impossible to measure recharge over large areas. In previous flow models of the SVRP aquifer, various approaches or techniques have been used to estimate areal recharge, ranging from assigning a uniform recharge to the entire model domain to calculating evapotranspiration for each model cell. An examination of previously developed recharge-calculation methods and their limitations is therefore needed to allow the SVRP aquifer modeling team to select and apply the most appropriate technique.

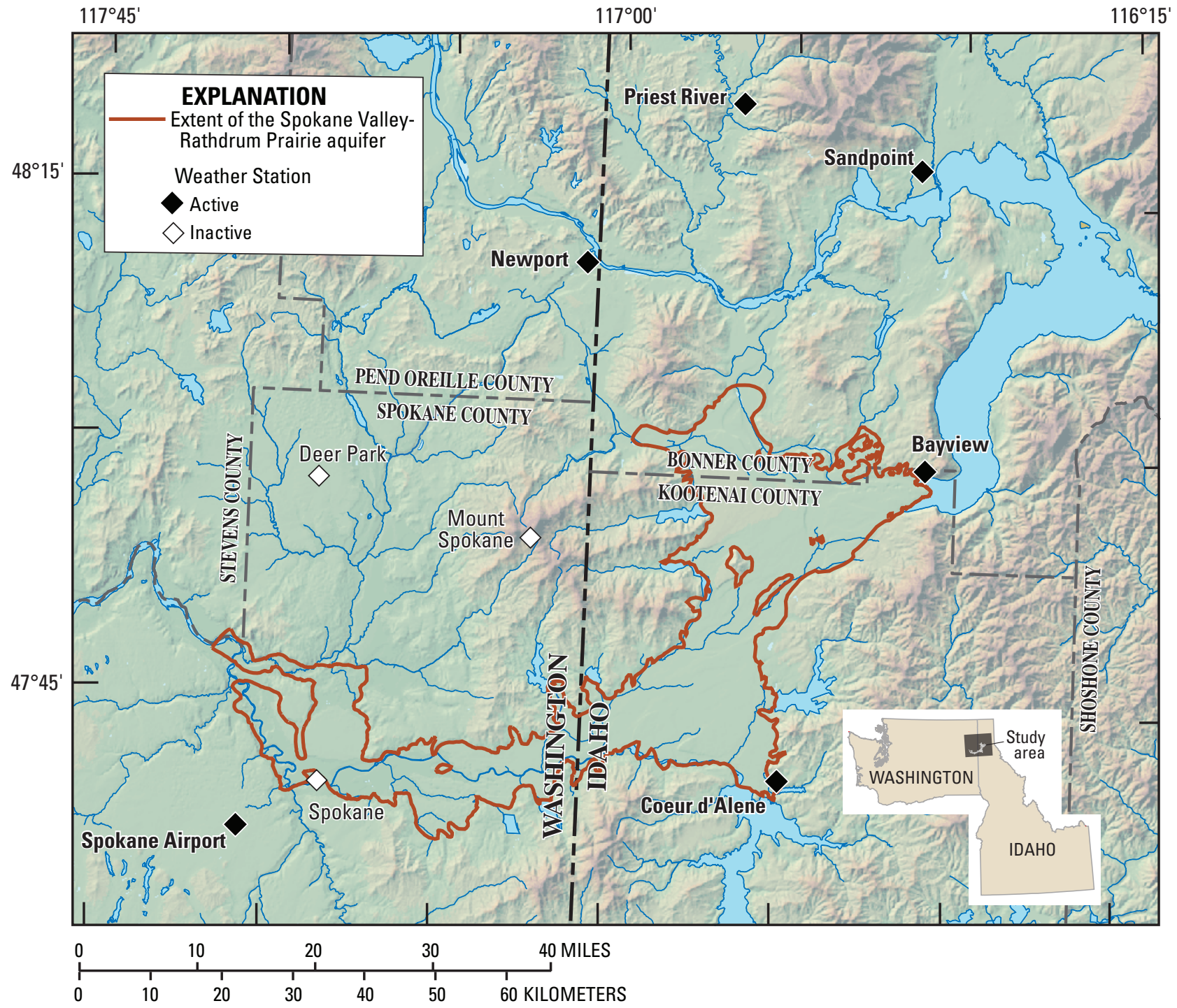

Figure 1. Location of the Spokane Valley-Rathdrum Prairie aquifer and National Weather Service stations in and near the study area. 


\section{Purpose and Scope}

This report describes four main methods for estimating areal recharge to the Spokane Valley-Rathdrum Prairie aquifer and provides recharge estimates for each method using data from weather stations in and near the study area. The limitations of each of the methods and the reliability of the recharge estimates are discussed. Because areal recharge is affected by soil hydrologic properties, those properties of the soils overlying the aquifer are briefly described in appendix A. The results of this analysis will be used by the SVRP aquifer modeling team to select an appropriate method for determining areal recharge for use in the flow model of the aquifer.

\section{Description of Study Area}

The Spokane Valley-Rathdrum Prairie aquifer underlies a relatively flat valley bottom with land-surface altitudes ranging from about 1,500 to nearly $2,600 \mathrm{ft}$. Ten lakes are located along the margins of the aquifer, the largest of which are Coeur d'Alene Lake and Lake Pend Oreille. Because the sediments of the valley floor are highly permeable, few distinct surface-drainage channels have developed other than the Spokane and Little Spokane Rivers.

Bedrock highlands of Precambrian metamorphic, Mesozoic and Cenozoic intrusive, and Tertiary basaltic rocks surround the valley. The valley is filled with Quaternary-age glaciofluvial sediments deposited during several catastrophic flood events from glacial Lake Missoula. The Spokane Valley-Rathdrum Prairie aquifer straddles the boundary between the Northern Rocky Mountain and Columbia Plateau physiographic provinces (Fenneman, 1931).

Ground water is the primary source for public-supply, domestic, irrigation, and industrial water use in the area, which led to the U.S. Environmental Protection Agency (USEPA) giving the aquifer "sole source" designation in 1978 (Kahle and others, 2005). Currently (2007), the aquifer is the source of drinking water for as many as 400,000 people.

A more complete description of the study area may be found in Kahle and others (2005).

\section{Climate}

Spokane has a mild, arid climate during the summer months but cold, coast-like conditions in the winter (U.S. Department of Commerce, 2005). Approximately 70 percent of the total annual precipitation falls between the first of October and the end of March and about one-half of that falls as snow. The growing season usually extends over nearly six months from mid-April to mid-October (U.S. Department of Commerce, 2005).

The entire study area is classified as $D s b$ under a modified Köppen system in which $D$ indicates a mean temperature of the warmest month greater than $10^{\circ} \mathrm{C}\left(40^{\circ} \mathrm{F}\right)$ and of the coldest month $0^{\circ} \mathrm{C}\left(32^{\circ} \mathrm{F}\right)$ or less; $s$ indicates that precipitation in the driest month of the summer half of the year is less than $40 \mathrm{~mm}$ (1.6 in.) and less than one-third of the precipitation amount in the wettest winter month; and $b$ indicates that the mean temperature of each of the four warmest months is $10^{\circ} \mathrm{C}\left(40^{\circ} \mathrm{F}\right)$ or greater and the mean temperature of the warmest month is less than $22^{\circ} \mathrm{C}\left(72^{\circ} \mathrm{F}\right)$ (Critchfield, 1983; Godfrey, 2000).

The National Weather Service (NWS) has nine weather stations in or within $20 \mathrm{mi}$ of the study area, although only six are active (table 1). Of these, only three are within or adjacent to the SVRP aquifer study area: Bayview Model Basin, Coeur D'Alene 1E, and Spokane Weather Service Office (WSO) Airport. Currently (2007), the closest AgriMet station to the study area is the Seven Bays Marina, Washington, (SBMW), near the confluence of the Spokane and Columbia Rivers, approximately $50 \mathrm{mi}$ west of Spokane (Bureau of Reclamation, 2006).

Table 1. National Weather Service stations in or near the study area.

[Western Regional Climate Center (2006a, 2006b). A bbreviations: ID, Idaho, WA, Washington; WSO, Weather Service Office. Symbols: -, currently (2007) in operation]

\begin{tabular}{|c|c|c|c|c|c|c|}
\hline \multirow{2}{*}{ Station name } & \multirow{2}{*}{$\begin{array}{l}\text { Station } \\
\text { number }\end{array}$} & \multirow{2}{*}{$\begin{array}{c}\text { Elevation } \\
\text { (feet above } \\
\text { vertical datum) }\end{array}$} & \multirow{2}{*}{ Latitude } & \multirow{2}{*}{ Longitude } & \multicolumn{2}{|c|}{ Dates in operation } \\
\hline & & & & & Starting & Ending \\
\hline Bayview Model Basin, ID & 100667 & 2,070 & $47^{\circ} 59^{\prime} \mathrm{N}$ & $116^{\circ} 33^{\prime} \mathrm{W}$ & $08-01-48$ & - \\
\hline Coeur D'Alene 1E, ID & 101956 & 2,160 & $47^{\circ} 41^{\prime} \mathrm{N}$ & $116^{\circ} 45^{\prime} \mathrm{W}$ & 08-01-1895 & - \\
\hline Deer Park 2E, WA & 452066 & 2,200 & $47^{\circ} 58^{\prime} \mathrm{N}$ & $117^{\circ} 26^{\prime} \mathrm{W}$ & 07-04-48 & $03-31-77$ \\
\hline Mount Spokane Summit, WA & 455674 & 5,890 & $47^{\circ} 55^{\prime} \mathrm{N}$ & $117^{\circ} 07^{\prime} \mathrm{W}$ & $07-01-53$ & $12-31-72$ \\
\hline Newport, WA & 455844 & 2,140 & $48^{\circ} 11^{\prime} \mathrm{N}$ & $117^{\circ} 03^{\prime} \mathrm{W}$ & $01-02-27$ & - \\
\hline Priest River Experiment Station, ID & 107386 & 2,380 & $48^{\circ} 21^{\prime} \mathrm{N}$ & $116^{\circ} 50^{\prime} \mathrm{W}$ & $12-07-11$ & - \\
\hline Sandpoint Experiment Station, ID & 108137 & 2,100 & $48^{\circ} 17^{\prime} \mathrm{N}$ & $116^{\circ} 34^{\prime} \mathrm{W}$ & $10-01-10$ & - \\
\hline Spokane WSO Airport, WA & 457938 & 2,360 & $47^{\circ} 37^{\prime} \mathrm{N}$ & $117^{\circ} 32^{\prime} \mathrm{W}$ & 01-01-1890 & - \\
\hline Spokane, WA & 457933 & 1,880 & $47^{\circ} 40^{\prime} \mathrm{N}$ & $117^{\circ} 25^{\prime} \mathrm{W}$ & $11-19-53$ & $10-31-83$ \\
\hline
\end{tabular}


Table 2. Summary of data from active weather stations in and near the Spokane Valley-Rathdrum Prairie area.

[Western Regional Climate Center (2006a, 2006b). Mean values are through December 31, 2005. A bbreviations: Exp. Stat., experiment station; WSO, Weather Service Office; ${ }^{\circ}$ F, degrees fahrenheit; in., inch; max., maximum; min., minimum]

\begin{tabular}{|c|c|c|c|c|c|c|}
\hline & \multicolumn{6}{|c|}{ Station name and number } \\
\hline & $\begin{array}{c}\text { Bayview } \\
\text { Model } \\
\text { Basin } \\
100667\end{array}$ & $\begin{array}{c}\text { Coeur } \\
\text { D' Alene } \\
1 E \\
101956\end{array}$ & $\begin{array}{c}\text { Newport } \\
455844\end{array}$ & $\begin{array}{c}\text { Priest River } \\
\text { Exp. Stat. } \\
107386\end{array}$ & $\begin{array}{l}\text { Sandpoint } \\
\text { Exp. Stat. } \\
108137\end{array}$ & $\begin{array}{c}\text { Spokane } \\
\text { WSO } \\
\text { Airport } \\
457938\end{array}$ \\
\hline Mean July max. temperature $\left({ }^{\circ} \mathrm{F}\right)$ & 79.6 & 85.0 & 85.3 & 82.6 & 81.9 & 83.9 \\
\hline Mean January min. temperature $\left({ }^{\circ} \mathrm{F}\right)$ & 21.0 & 21.8 & 18.2 & 18.1 & 20.3 & 21.6 \\
\hline Mean January max. temperature $\left({ }^{\circ} \mathrm{F}\right)$ & 34.7 & 34.6 & 31.8 & 30.4 & 32.3 & 33.0 \\
\hline Mean annual temperature $\left({ }^{\circ} \mathrm{F}\right)$ & 50.3 & 53.4 & 51.8 & 50.3 & 51.1 & 52.8 \\
\hline Mean annual precipitation (in.) & 24.1 & 25.2 & 26.2 & 31.1 & 32.0 & 16.1 \\
\hline Mean annual snowfall (in.) & 37.9 & 46.0 & 58.0 & 81.8 & 70.5 & 41.0 \\
\hline Mean snow depth (in.) & 1.0 & 1.0 & 3.0 & 5.0 & 2.0 & 1.0 \\
\hline
\end{tabular}

Mean annual temperatures at the six active NWS stations in and near the study area range from $44.9^{\circ} \mathrm{F}$ at Bayview Model Basin to $48^{\circ} \mathrm{F}$ at Coeur D'Alene $1 \mathrm{E}$ and at Spokane WSO Airport. The coldest month in the area is January, with mean low temperatures ranging from $18.1^{\circ} \mathrm{F}$ at Priest River Experiment Station to $21.8^{\circ} \mathrm{F}$ at Coeur D'Alene 1E. The warmest month is July, with mean high temperatures ranging from $79.6^{\circ} \mathrm{F}$ at Bayview Model Basin to $85.3^{\circ} \mathrm{F}$ at Newport (table 2; Western Regional Climate Center, 2006a, 2006b). Mean annual precipitation ranges from 16.1 in. at Spokane WSO Airport to about 32 in. at Sandpoint Experiment Station (Western Regional Climate Center, 2006a, 2006b). July and August are typically the driest months and November, December, and January the wettest.

Of the six active stations, only Spokane WSO Airport collects meteorological parameters beyond temperature, precipitation, and snow depth. This limits the ability to calculate evapotranspiration and recharge at each of the other stations by methods requiring such data as wind speed or relative humidity. Table 3 summarizes the meteorological data necessary to calculate recharge by each of the four main methods discussed in this report.

None of the three currently (2007) active stations in or adjacent to the study area have mean maximum temperatures of less than $32^{\circ} \mathrm{F}$ for any month (table 2). Therefore, recharge probably occurs throughout the winter and no adjustment is needed to winter recharge timing due to melting snowpack.

\section{Types of Evapotranspiration}

Any calculation of areal recharge must account for evapotranspiration as well as precipitation. Because the methods discussed in this report use different definitions of evapotranspiration, short definitions are given here:
Potential evapotranspiration (PET) is the "evapotranspiration rate of short, actively transpiring vegetation (e.g., grass) that: completely covers the ground; is well-supplied with water; and exerts negligible resistance to water movement through the plant" (Tindall and others, 1999). If sufficient water were available, $P E T$ indicates the amount of water that could undergo evapotranspiration. $P E T$ is a climatic parameter because it denotes the evaporation power of the atmosphere. In order to determine actual evapotranspiration, a crop coefficient must be included.

Table 3. Summary of meteorological data necessary for recharge calculations.

[A bbreviations: USDA, U.S. Department of Agriculture; ESPAM, Eastern Snake Plain Aquifer Model; FAO, Food and Agriculture Organization; max., maximum; min., minimum]

\begin{tabular}{|c|c|c|c|c|}
\hline \multirow[b]{2}{*}{ Data } & \multicolumn{4}{|c|}{ Recharge calculation method } \\
\hline & Langbein & USDA & ESPAM & $\begin{array}{c}\text { FAO } \\
\text { Penman- } \\
\text { Monteith }\end{array}$ \\
\hline $\begin{array}{l}\text { Precipitation } \\
\text { Potential evapotranspiration } \\
\text { Temperature, mean } \\
\text { Temperature, max. } \\
\text { Temperature, min. } \\
\text { Altitude } \\
\text { Latitude } \\
\text { Relative humidity, min. } \\
\text { Relative humidity, max. } \\
\text { Percent of possible sunshine } \\
\text { Wind speed } \\
\text { Dew point }\end{array}$ & $\begin{array}{l}\bigcirc \\
\bigcirc\end{array}$ & $\begin{array}{l}0 \\
0 \\
0\end{array}$ & 0 & $\begin{array}{l}0 \\
0 \\
0 \\
0 \\
0 \\
0 \\
0 \\
0 \\
0 \\
0 \\
0\end{array}$ \\
\hline $\begin{array}{l}\text { Annual data only } \\
\text { Variable time period }\end{array}$ & $\begin{array}{l}0 \\
0\end{array}$ & & & \\
\hline
\end{tabular}


Consumptive use (or actual evapotranspiration), as defined in U.S. Department of Agriculture (USDA; 1970), is "the amount of water used by the vegetative growth of a given area in transpiration and building of plant tissue and that evaporated from adjacent soil or intercepted precipitation on the plant foliage in any specified time."

Reference crop evapotranspiration $\left(E T_{0}\right)$ is the evapotranspiration rate from a reference surface (a hypothetical grass reference crop with specific characteristics) that is not short of water. It also denotes the evaporation power of the atmosphere and thus is a climatic parameter (Allen and others, 1998). As with PET, in order to determine actual evapotranspiration, a crop coefficient must be included.

Crop evapotranspiration under standard conditions $(E T)$ is the evapotranspiration rate from "disease-free, wellfertilized crops, grown in large fields, under optimum soil water conditions, and achieving full production under the given climatic conditions" (Allen and others, 1998).

Crop evapotranspiration under non-standard conditions $\left(E T_{c a d j}\right)$ is the evapotranspiration rate from fields with less than optimal environmental factors such as "pests and diseases, soil salinity, low soil fertility, water shortage or water logging" (Allen and others, 1998).

\section{Description of Recharge-Estimation Techniques}

Four potential approaches were identified for determining areal recharge for the SVRP ground-water flow model:

1. A method developed by Langbein (1961) in which recharge is estimated on the basis of empirical data from other basins;

2. A method developed by the U.S. Department of Agriculture (1970) in which crop consumptive use and effective precipitation are first calculated and then subtracted from actual precipitation to yield an estimate of recharge;

3. An approach developed by Contor (2004) for the Eastern Snake Plain Aquifer Model (ESPAM) Enhancement Project in which recharge is calculated on the basis of precipitation-recharge relations from other basins; and

4. An approach in which reference evapotranspiration is calculated by the Food and Agriculture Organization (FAO) Penman-Monteith equation (Allen and others, 1998), crop consumptive use is determined (using a single or dual coefficient approach), and the amount of water which passes through the plant root zone (and thus becomes recharge) is calculated.
These four methods will henceforth be referred to by Langbein, USDA, ESPAM, and FAO Penman-Monteith, respectively.

In the following discussion, the names of variables are reported essentially as those names are used in the original reference, both to preserve the sometimes subtle differences in the original authors' definitions and to facilitate comparison with the original work. Thus, some variable names may be duplicated between and within the equations describing the different approaches, though with different meanings. For this reason, variables are defined for each equation, thereby introducing some repetitiveness.

\section{Previous Work}

The most recent estimates of areal recharge to the SVRP aquifer system were made for application in groundwater flow models. Because the purpose, model code, and simulated area vary among the various models, recharge estimates (especially volumetric estimates) may not be directly comparable and are best viewed as approximate comparisons.

In their finite-element ground-water flow model of the Spokane area, Bolke and Vaccaro (1981) used the USDA method described below to determine effective rainfall, which was then subtracted from precipitation to determine recharge. Precipitation, evapotranspiration, and recharge values were applied uniformly over the model domain. For their steady-state, time-averaged simulation, they used values of $1.72 \mathrm{in} / \mathrm{mo}$ for precipitation and $1.31 \mathrm{in} / \mathrm{mo}$ for potential evapotranspiration (or 209 and $143 \mathrm{ft}^{3} / \mathrm{s}$, respectively). For the transient simulation, Bolke and Vaccaro used monthly precipitation and potential and actual evapotranspiration values from May 1977 to April 1978; their calculated recharge ranged from 0 to about $4.5 \mathrm{in} / \mathrm{mo}$ (or maximum values of 216 and $98 \mathrm{ft}^{3} / \mathrm{s}$, for precipitation and evapotranspiration, respectively).

The CH2M Hill (1998) finite-element ground-water flow model of the Spokane area redistributed the $66 \mathrm{ft}^{3} / \mathrm{s}$ annual steady-state recharge used by Bolke and Vaccaro (1981) to reflect spatial variation in precipitation based on the work of Olness (1993). During calibration of the CH2M Hill model, the areal recharge was adjusted, resulting in an areal-recharge volume less than half of Bolke and Vaccaro's value.

Buchanan (2000) constructed a finite-difference groundwater flow model of the entire Spokane Valley-Rathdrum Prairie aquifer. Recharge was estimated to be 25 percent of precipitation volume and was varied areally, resulting in recharge rates ranging from 0.017 to $0.028 \mathrm{in} / \mathrm{d}$.

Golder Associates, Inc. (2004) constructed integrated ground-surface-water models of the Little Spokane (WRIA 55) and Middle Spokane (WRIA 57) watersheds using the MIKE SHE modeling program, in which the ground-water 
component is calculated by the finite-difference method (DHI software, 2006). The MIKE SHE code allows precipitation and evapotranspiration to be specified separately, thus monthly potential evapotranspiration estimates were made using the Blaney-Criddle FAO method (Doorenboos and Pruitt, 1977) and precipitation was varied areally using the Parameterelevation Regressions on Independent Slopes Model (PRISM) data (Daly and others, 1994, 1997, 1998). Golder Associates, Inc. (2004) specified evapotranspiration as 74 percent of annual precipitation in the Middle Spokane watershed model, and 64 percent of precipitation in the Little Spokane watershed model. An approximation of these recharge rates can be made by subtracting evaporation from precipitation and applying the mean annual rainfall of 17.62 in. at the discontinued Spokane weather station for the Middle Spokane watershed and 22.44 in. at the discontinued Deer Park 2E weather station for the Little Spokane watershed, yielding recharge rates of 0.38 and $0.67 \mathrm{in} / \mathrm{mo}$, respectively.

These and other values of areal recharge used by previous workers for water budgets and ground-water flow models of the SVRP aquifer area are described in Kahle and others (2005).

\section{Langbein Method}

The Langbein method was developed as part of a study of the water resources of the Raft River basin, Idaho and Utah (Langbein, 1961). Because the basin was largely uninstrumented, it was necessary to estimate water yield by indirect means, and the resulting method is based on empirical relations developed on the basis of data from other drainage basins across the United States. The same methodology was later applied by Chapman and Young (1972) in the study of an area immediately east of the Raft River basin.

As applied in the Raft River basin, the derivation of basin yield was a multi-step process. First, mean annual temperatures and mean annual precipitation for the basin were calculated using relations between these parameters and elevation developed from nearby and regional weather stations; the areal distribution of precipitation was then corrected for local topographic effects. Next, using the results of earlier work by Langbein and others (1949) that defined a relation between mean annual temperature and potential evapotranspiration, values for potential evapotranspiration were derived for the basin. In the third step, the ratio of annual precipitation to potential evapotranspiration was calculated, and using relations developed for other basins across the United States (Langbein and others, 1949), the ratio of runoff to potential evapotranspiration was obtained. Finally, these values were incorporated in an equation that is solved for the value of basin yield or runoff:

$$
R_{a}=L_{a} \frac{P_{a}}{L_{a}}
$$

where

$$
\begin{aligned}
& R_{a} \text { is annual basin yield or runoff, in inches, } \\
& L_{a} \quad \text { is annual potential evapotranspiration, } \\
& \quad \text { in inches, and } \\
& P_{a} \quad \text { is annual precipitation, in inches. }
\end{aligned}
$$

The graph relating mean annual temperature and potential evapotranspiration is available in Langbein and others (1949), Langbein (1961), and Chapman and Young (1972). The graph relating $P_{a} / L_{a}$ to $R_{a} / L_{a}$ is available in Langbein (1961) and Chapman and Young (1972). Alternatively, B.A. Contor (Idaho State University, written commun., March 9, 2006) derived a regression equation with a correlation coefficient $\left(R^{2}\right)$ of 0.96 describing the relations in the latter graph:

$$
\begin{aligned}
\frac{R_{a}}{L_{a}} & =\left(0.16534831-0.63978817\left(\frac{P_{a}}{L_{a}}\right)\right. \\
& +0.772829589\left(\frac{P_{a}}{L_{a}}\right)^{2}-0.117252503\left(\frac{P_{a}}{L_{a}}\right)^{3},
\end{aligned}
$$

where

$R_{a}$ is annual basin yield or runoff, in inches,

$L_{a} \quad$ is annual potential evapotranspiration, in inches, and

$P_{a} \quad$ is annual precipitation, in inches.

At low values of precipitation, this equation calculates runoff values greater than precipitation, thus Contor applied an alternative linear calculation for $P_{a} / L_{a}$ ratios less than 0.55 :

$$
\frac{R_{a}}{L_{a}}=\left(\frac{P_{a}}{L_{a}}\right) 0.04,
$$

where

$R_{a}$ is annual basin yield or runoff, in inches,

$L_{a}$ is annual potential evapotranspiration, in inches, and

$P_{a} \quad$ is annual precipitation, in inches.

As used here, it is assumed that basin yield is equal to ground-water recharge because the sediments that compose the SVRP valley floor are highly permeable, and little surface drainage reaches the Spokane and Little Spokane Rivers. An important limitation of the method is that it is applicable only to annual time periods. To calculate values for shorter time increments, annual values must be divided by some scheme such as simple division. 


\section{USDA Method}

The USDA method is based on the Blaney-Criddle formula (Blaney and Criddle, 1962) for calculating crop consumptive use:

$$
U=K F,
$$

where

$$
\begin{aligned}
& U \quad \begin{array}{l}
\text { is seasonal consumptive use of water, } \\
\text { in inches, }
\end{array} \\
& K \quad \text { is empirical seasonal consumptive-use } \\
& \text { crop coefficient, dimensionless, and } \\
& F \quad \text { is sum of monthly consumptive use } \\
& \text { factors for the growing season, } \\
& \text { dimensionless. }
\end{aligned}
$$

Equation 4 is then restated for monthly consumptive use as:

$$
u=k f
$$

where

$u$ is monthly consumptive use of water, in inches,

$k$ is empirical monthly consumptive-use crop coefficient, dimensionless, and

$f \quad$ is monthly consumptive use factor for the growing season, dimensionless.

The monthly consumptive use factor $(f)$ is calculated with equation 6 :

$$
f=\frac{t p}{100}
$$

where

$f$ is monthly consumptive use factor for the growing season, dimensionless,

$t \quad$ is mean air temperature, ${ }^{\circ} \mathrm{F}$, and

$p \quad$ is percentage of daylight hours in the year.

Representative values for $K$ and $k$ are given in Blaney and Criddle (1962).
In order to refine the calculation of the consumptive use crop coefficient $(k)$ for application to shorter time periods with more climatic variability, U.S. Department of Agriculture (1970) describes a modification of the Blaney-Criddle formula where $k$ is calculated by:

$$
k=k_{t} k_{c}
$$

where

$k \quad$ is empirical monthly consumptive use crop coefficient, dimensionless,

$k_{t} \quad$ is climatic coefficient related to mean air temperature, dimensionless, calculated as: $k_{t}=0.0173 t-0.314$,

$t \quad$ is mean air temperature, ${ }^{\circ} \mathrm{F}$, and

$k_{c} \quad$ is crop growth-stage coefficient, dimensionless (U.S. Department of Agriculture, 1970).

To calculate consumptive use, effective rainfall must be known, defined as the amount of precipitation that is available for crop consumptive use. The equation given in U.S. Department of Agriculture (1970) for effective rainfall is:

$$
r_{e}=\left(0.70917 r_{t}^{0.82416}-0.11556\right)(10)^{0.02426 u}(f)
$$

where

$$
\begin{array}{cl}
r_{e} & \text { is effective rainfall, in inches, } \\
r_{t} & \text { is mean rainfall, in inches, } \\
u & \text { is potential consumptive use, in inches, } \\
f & \text { is } 0.531747+0.295164 D-0.057697 D^{2} \\
& +0.003804 D^{3} \text {, and }
\end{array}
$$

$D$ is net depth of water application, in inches. (Note that the $f$ in equation 8 is different than $f$ in equations 5 and 6.)

Potential consumptive use $(u)$ can be taken as either potential evapotranspiration or calculated with equations 5,6 , and 7, yielding:

$$
u=(0.0173 t-0.314) k_{c}\left(\frac{t p}{100}\right)
$$

where

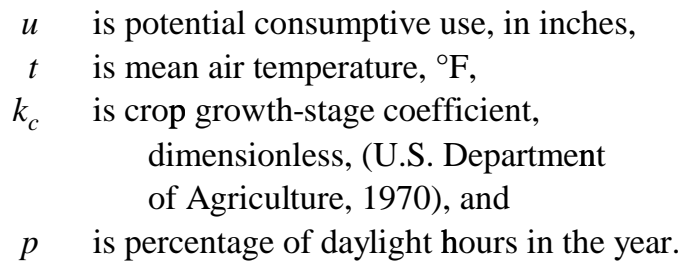


Values for $r_{t}, t$, and $p$ can be specified for annual, monthly, or shorter time periods. If the calculated effective rainfall $\left(r_{e}\right)$ exceeds either the mean rainfall $\left(r_{t}\right)$ or mean consumptive use $(u)$, it must be set to the lower of the latter two values.

In their transient ground-water flow model of the Spokane Valley, Bolke and Vaccaro (1981) used the USDA method to determine effective rainfall and assumed that effective rainfall was equal to actual evapotranspiration, thus yielding equation 10 , the amount of recharge from precipitation:

$$
R=r_{t}-r_{e}
$$

where

$\begin{array}{ll}R & \text { is recharge from precipitation, in inches, } \\ r_{t} & \text { is precipitation, in inches, and } \\ r_{e} & \text { is effective rainfall, in inches. }\end{array}$

Bolke and Vaccaro (1981) further assumed mean monthly consumptive use $(u)$ was equal to potential evapotranspiration at Spokane.

In preparing data sets for the SVRP aquifer model, B.A. Contor (written commun., March 9, 2006) determined that for low values of precipitation, effective precipitation can be negative as a result of using values lower than those used to develop the non-linear regression. Consequently, for precipitation amounts less than 0.96 in., he developed equation 11 to calculate effective precipitation $\left(r_{e}\right)$ :

$$
r_{e}=r_{t}(1-(0.700691-0.02543 u))
$$

where

$r_{e}$ is monthly effective rainfall, in inches,

$r_{t}$ is monthly mean rainfall, in inches, and

$u$ is monthly mean crop consumptive use, in inches.

The central assumption in applying this method to determination of recharge is that any precipitation not necessary for plant growth (evapotranspiration) is recharged to ground water.

\section{ESPAM Method}

As part of the Eastern Snake Plain Aquifer Model Enhancement Project (ESPAM), a geographic information system (GIS)-based method was developed to calculate recharge based on the PRISM gridded maps of monthly precipitation (Daly and others, 1994, 1997, 1998) and generalized soil maps (Contor, 2004; Cosgrove and others,
2006). The calculations are based on earlier work by Rich (1951, 1952), who measured water yield from basins with forest and rangeland vegetation in the Sierra Ancha experimental forest in central Arizona. Rich $(1951,1952)$ plotted runoff against precipitation for several watersheds to produce a separate curve for each basin. Contor (2004) fit equations to these curves yielding:

$$
U=K \times F^{N},
$$

where

$U$ is basin yield or runoff, in feet per month,

$K$ is empirical slope parameter, dimensionless,

$F$ is precipitation, in feet per month, and

$N$ is empirical coefficient for curvature, dimensionless.

(Note that the variable names and definitions have changed from equations 1-11.)

Contor (2004) further modified Rich's method in several ways in order to apply it to the shorter time periods and geologic conditions required by the ESPAM model. Like the SVRP aquifer area, most of the eastern Snake River Plain (ESRP) has little surface-water drainage that reaches the main through-flowing river, and Contor assumed that basin yield was equal to recharge. Thus:

$$
R=K \times P^{N}
$$

where

$R$ is recharge from precipitation, in feet per month,

$K$ is empirical slope parameter, dimensionless,

$P$ is precipitation, in feet per month, and

$N$ is empirical coefficient for curvature, dimensionless.

This relation is based on the assumption that a plot of recharge against precipitation has a low slope until sufficient precipitation occurs to exceed the requirements of soilmoisture storage, ponding, evaporation, and transpiration, after which recharge occurs. At higher values of precipitation, the curve would become linear and approach a slope of 1 (however, although Rich's $(1951,1952)$ data were collected over 15 years, with one year exceeding 200 percent of the mean precipitation, annual precipitation was still insufficient to reach this threshold). The distance the recharge curve is offset from the 1:1 line is controlled by the potential for precipitation to be diverted to the other pre-recharge precipitation requirements mentioned above. The degree 
of curvature in the early, exponential part of the curve is controlled by preferential recharge pathways within the soil profile, and any surface concentration of precipitation due to topography. The application of the method to shorter time periods changes the relative importance of each of these other pre-recharge requirements; thus the equation parameters are dependent on the time-step length selected and also are unit-dependent. Contor (2004) used annual recharge values and generalized soil types from a previous ESRP groundwater flow model (Garabedian, 1992) to develop monthly parameters for three different soil types: lava rock $(K=0.69$, $N=1.2)$, thin soil $(K=0.463, N=1.5)$, and thick soil $(K=0.136$, $N=2$ ), where the units are in feet per month. These parameters were calibrated to match annual volumes of recharge used in the previous modeling effort by Garabedian (1992) as well as to match the curvature and transition points suggested by theoretical monthly values of pre-recharge precipitation requirements for each of the three soil types. Garabedian (1992), in turn, based his annual recharge values on those of Mundorff and others (1964), who used a simple precipitation to water-yield ratio derived from eight basins draining to the ESRP.

Because recharge cannot exceed precipitation, the slope of the recharge-precipitation line cannot exceed one. Low values of precipitation must first satisfy the pre-recharge requirements of soil-moisture storage, ponding, evaporation, and transpiration before recharge can occur, resulting in a nonlinear recharge curve. With increasing precipitation, these pre-recharge requirements are satisfied, the curve becomes linear, and there is a one-to-one linear relation between additional precipitation and additional recharge. To automate the calculation of recharge values, Contor derived the transition point - the point where the line makes the transition from exponential to linear and the non-linear function reaches a slope of one-defined as:

$$
P_{T}=\left(\frac{1}{N K}\right)^{\left(\frac{1}{N-1}\right)},
$$

where

$P_{T} \quad$ is transition precipitation, in feet per month,

$K$ is empirical slope parameter, dimensionless, and

$N$ is empirical coefficient for curvature, dimensionless.
Thus, for precipitation amounts less than the transition precipitation $\left(P_{T}\right)$, equation 13 is used to determine recharge; for amounts greater than $P_{T}$, equation 15 is used:

$$
R=R_{T}+P-P_{T}
$$

where

$R$ is recharge from precipitation, in feet per month,

$R_{T} \quad$ is recharge calculated from transition precipitation, in feet per month,

$P \quad$ is precipitation, in feet per month, and

$P_{T} \quad$ is transition precipitation, in feet per month.

Contor (2004) further modified Rich's approach by cumulatively applying precipitation for November through February as if it all occurred in February. This procedure was followed because winter-time recharge is increased owing to decreased evapotranspiration and temporal concentration of recharge resulting from episodic snow accumulation and melting. This adjustment implies that all snowfall accumulates until a single February thaw event. While this would be unrealistic in the SVRP aquifer area where thaw events are more frequent than in the ESRP, reduced evapotranspiration and episodic snow and melting events would still occur. To address these processes but to avoid applying all winter recharge in February, Contor proposed multiplying winter precipitation by four before recharge is calculated and then dividing the calculated recharge by four, resulting in precipitation/recharge ratios that are less affected by the prerecharge factors and thus increasing recharge (B.A. Contor, written commun., September 11, 2006).

\section{FAO Penman-Monteith Method}

Another approach to the determination of recharge is to calculate actual (versus potential) evapotranspiration (accounting for processes such as soil-moisture storage and direct evaporation) and determine the amount of precipitation that passes through the root zone (and thus becomes recharge). The difficulty lies with determination of actual evapotranspiration without extensive field measurements.

Due to shortcomings in other methods for estimating reference evapotranspiration, including the earlier BlaneyCriddle FAO method, the FAO developed an approach dubbed the FAO Penman-Monteith equation (Allen and others, 1998). 
The reference evapotranspiration calculated with this newer equation is then used with crop evapotranspiration coefficients to estimate crop-water requirements. The FAO PenmanMonteith equation for calculating reference evapotranspiration is:

$$
E T_{o}=\frac{0.048 \Delta\left(R_{n}-G\right)+\gamma \frac{900}{T+273} u_{2}\left(e_{s}-e_{a}\right)}{\Delta+\gamma\left(1+0.34 u_{2}\right)}
$$

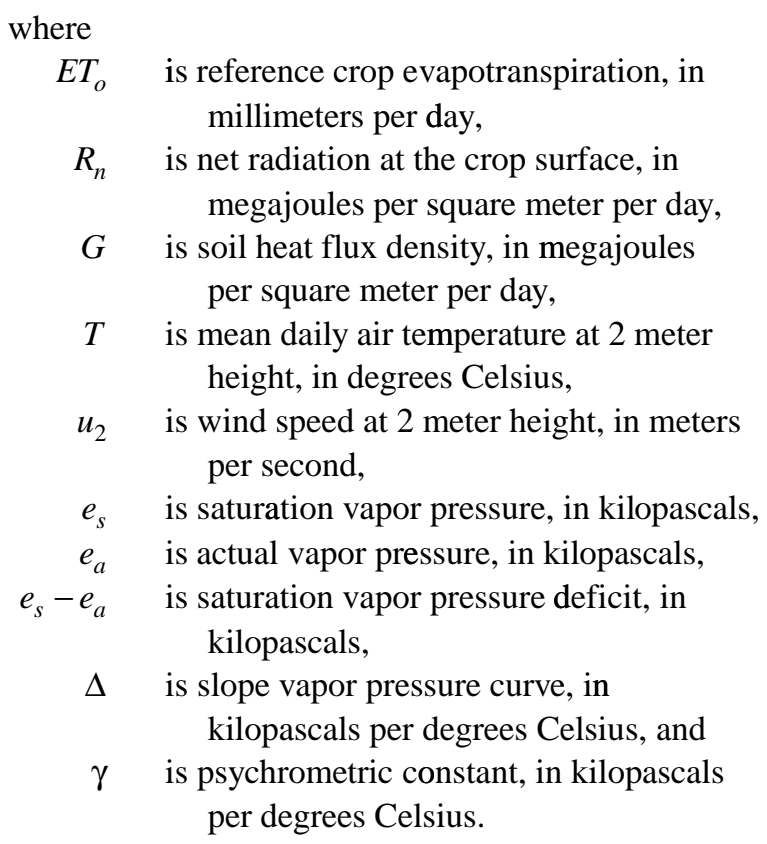

One of the characteristics of the FAO Penman-Monteith approach is an emphasis on applicability. Because most of these parameters are not commonly measured, Allen and others (1998) devoted a chapter in their paper to their calculation with commonly available meteorological data.

To calculate crop consumptive use (under standard conditions), the reference evapotranspiration $\left(E T_{o}\right)$ is multiplied by a crop coefficient $\left(K_{c}\right)$ :

$$
E T_{c}=K_{c} E T_{o} \text {, }
$$

The crop coefficient $\left(K_{c}\right)$ for specific crops may be calculated using procedures described in Allen and others (1998). To refine crop-water requirement estimates, these calculations account for growth stage. Alternatively, typical values for $K_{c}$ are available in the literature. It is important to note that $K_{c}$ values usually are given for either a grass or alfalfa reference crop; the coefficients given in Allen and others (1998) are for grass. To convert alfalfa-referenced $K_{c}$ values to grass-referenced $K_{c}$ values, $K_{c}$ is multiplied by a factor ranging from 1.0 to 1.3 , depending on climate. For Kimberly, Idaho (in south-central Idaho), the conversion factor is 1.24 (Allen and others, 1998).

In this report, the initial attempt to use the FAO PenmanMonteith method to determine recharge simply subtracts crop evapotranspiration $(E T)$ from precipitation. This approach is hereafter referred to as the single-coefficient FAO PenmanMonteith method.

The FAO Penman-Monteith method can be carried a step further by splitting the crop coefficient $\left(K_{c}\right)$ into two components: the basal crop coefficient $\left(K_{c b}\right)$, which accounts for crop transpiration, and the soil evaporation coefficient $\left(K_{e}\right)$. This calculation of dual-crop evapotranspiration $\left(E T_{c d}\right)$ allows estimation of the effects of specific wetting events on $K_{c}$ and was intended for daily calculation of irrigation requirements. The equation for dual-crop evapotranspiration is:

$$
E T_{c d}=\left(K_{c b}+K_{e}\right) E T_{O},
$$

where

$$
\begin{aligned}
& E T_{c d} \text { is dual-crop evapotranspiration, in } \\
& \text { millimeters per day, } \\
& K_{c b} \text { is basal crop coefficient, dimensionless, } \\
& K_{e} \text { is soil evaporation coefficient, } \\
& \text { dimensionless, and } \\
& E T_{O} \text { is reference evapotranspiration, in } \\
& \text { millimeters per day. }
\end{aligned}
$$

The basal crop coefficient $\left(K_{c b}\right)$ for specific crops is available in Allen and others (1998) or in other literature. The soil evaporation coefficient is calculated using constants and procedures described in Allen and others (1998). where

$E T_{c}$ is crop evapotranspiration, in millimeters per day,

$K_{c} \quad$ is crop coefficient, dimensionless, and

$E T_{o}$ is reference evapotranspiration, in millimeters per day. 
Deep percolation from the soil zone can be calculated by a simple mass-balance approach that assumes deep percolation is equal to recharge. Thus, this equation yields recharge for the dual-coefficient FAO Penman-Monteith method:

$$
D P_{i}=\left(P_{i}-R O_{i}\right)+I_{i}-E T_{c d, i}-D_{r, i-1} \quad \geq 0,
$$

where

$D P_{i} \quad$ is water loss out of the root zone by deep percolation on day $i$, in millimeters,

$P_{i} \quad$ is precipitation on day $i$, in millimeters,

$R O_{i}$ is runoff from the soil surface on day $i$, in millimeters,

$I_{i} \quad$ is net irrigation depth on day $i$ that infiltrates the soil, in millimeters,

$E T_{c d, i}$ is dual-crop evapotranspiration on day $i$, in millimeters, and

$D_{r, i-1}$ is root zone depletion at the end of the previous day, $i-1$, in millimeters.

Further adjustments to crop consumptive use for nonstandard conditions can be made to account for environmental stresses and constraints on crop growth such as pests, soil salinity, water-logging, or drought. These techniques are not considered in this report because they cannot be reliably applied over a large area.

\section{Recharge Calculations and Discussion}

As a first step, data from the six active NWS stations in and near the study area (Bayview Model Basin, Coeur D'Alene 1E, Newport, Sandpoint Experiment Station, Priest River Experiment Station, and Spokane WSO Airport) were used to calculate mean monthly recharge using equations and methods described above: the Langbein, USDA, ESPAM, and single-coefficient FAO Penman-Monteith methods. Annual and monthly mean temperature and precipitation values used for the recharge calculations are for each station's period of record through December 2005 (Western Regional Climate Center, 2006a, 2006b).

Apparent limitations of the mean monthly recharge calculations led to a second step in which daily recharge values for the six weather stations were calculated by using equations for the (dual-coefficient) FAO Penman-Monteith dual-crop evapotranspiration $\left(E T_{c d}\right)$ and deep percolation. Daily observations for temperature and precipitation for the period 1990-2005 were used for each station; however, wind speed for Spokane WSO Airport was applied to all stations (U.S. Department of Commerce, 2006).

\section{Mean Monthly Recharge}

Annual recharge values for each weather station and recharge method are shown in figure 2 . These annual values were calculated by summing calculated mean monthly recharge values, except for the Langbein method, for which annual means were used in the calculations.

Annual recharge values calculated by the Langbein method are shown in table 4 and figure 2. Mean annual precipitation data were obtained from published annual means (Western Regional Climate Center, 2006a, 2006b) and mean annual potential evapotranspiration values for Bayview Model Basin, Coeur D'Alene 1E, and Sandpoint Experiment Station were taken from Allen and Brockaway (1983). For the remaining three stations-Priest River Experiment Station, Newport, and Spokane WSO Airport-Allen and Brockaway's (1983) mean annual potential evapotranspiration value for Coeur D'Alene 1E was used.

The Langbein-method annual recharge for all six weather stations ranged from less than 1 percent to 11 percent of mean annual precipitation, yielding the lowest annual recharge values of the methods discussed in this report. The primary shortcoming of the Langbein method is that it can be applied only to annual time periods. For application to shorter periods, the annual values must be apportioned by some scheme, leading to further uncertainty. Furthermore, the previously stated assumption that basin yield is equal to basin recharge may not be valid: because the method was originally developed to determine runoff (as streamflow) from a basin, it does not account for subsurface underflow. Thus calculated recharge may be lower than actual recharge. In addition, basin yield does not equal recharge where there is significant surface-water runoff from lands within the study area. Finally, because independent mean annual potential evapotranspiration values were unavailable for three stations, the use of the Coeur D'Alene $1 \mathrm{E}$ estimate adds to the uncertainty.

The USDA-method mean monthly recharge was calculated using mean monthly crop growth stage coefficients $\left(k_{c}\right)$ for alfalfa from curve number 2 in U.S. Department of Agriculture (1970). Values for potential consumptive use $(u)$ were calculated using equation 9; however, the minimum daily value was assumed to be $1 \mathrm{~mm} / \mathrm{d}$ based on the maximum measured winter evapotranspiration at Kimberly, Idaho (Wright, 1993). Because this paper is concerned with recharge from precipitation, the net depth of applied irrigation water (D) was assumed to be 0 .

Calculated mean monthly recharge ranged from 53 to 73 percent of mean monthly precipitation. Annual recharge ranged from 64 to 69 percent of mean annual precipitation (table 5). The method by which potential consumptive use $(u)$ is selected-either potential evapotranspiration or from equation 9-affects calculated recharge, with equation 9 yielding a lower value of $u$, thus a higher recharge value. 


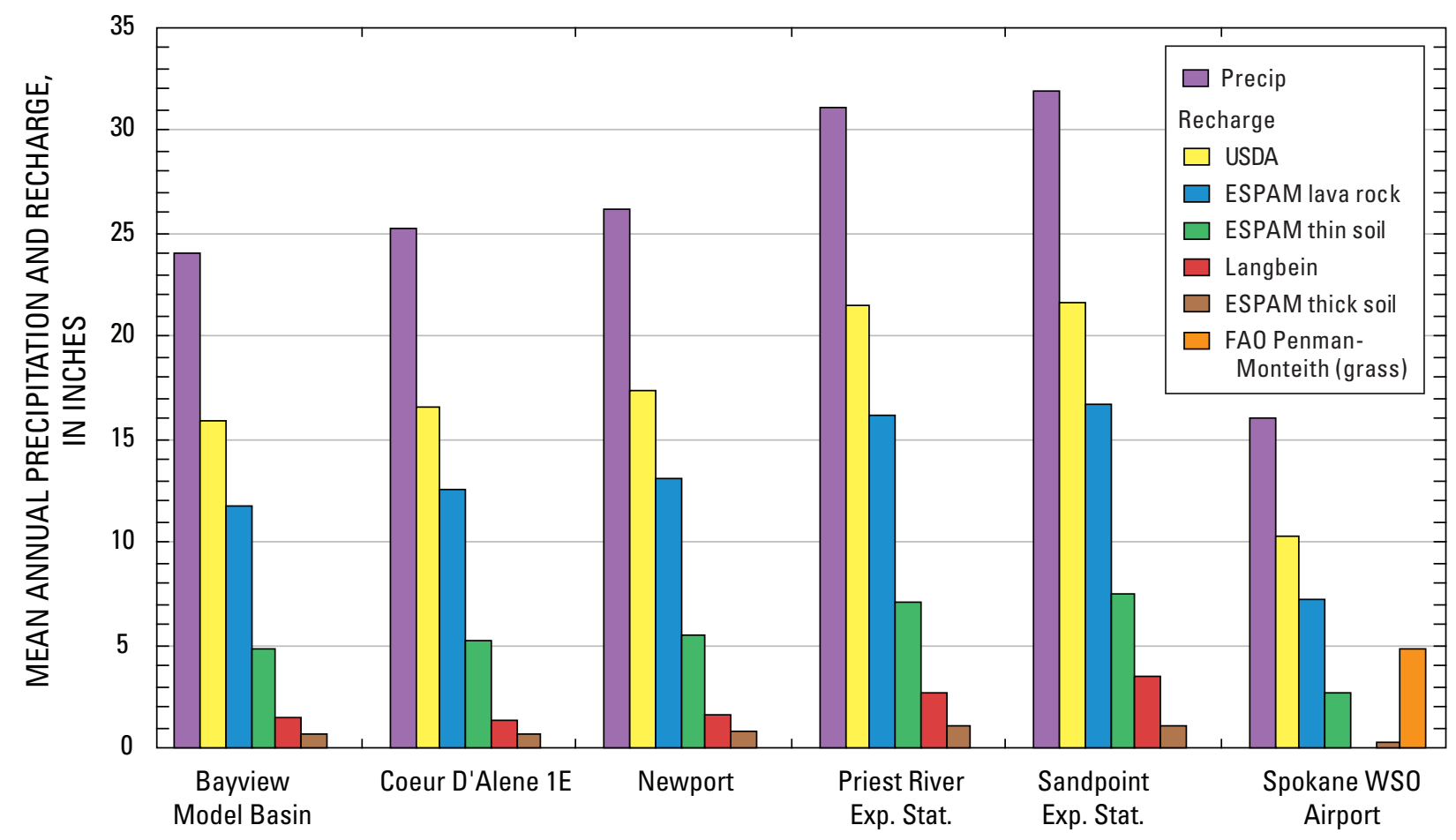

NATIONAL WEATHER SERVICE STATION

Figure 2. Mean annual precipitation and recharge calculated by various methods at six weather stations in the study area.

Furthermore, the USDA effective rainfall equation (equation 8) was derived empirically through the "analysis of 50 years of precipitation records" at 22 weather stations representing all climatic conditions in the conterminous United States (U.S. Department of Agriculture, 1970). Thus, it is difficult to evaluate how applicable the method is to the SVRP aquifer study area.

Mean monthly recharge calculations for the ESPAM method were made using thin-soil, thick-soil, and lava-rock parameters: transition precipitation $\left(P_{T}\right)$ was calculated as $2.07,3.68$, and $2.57 \mathrm{ft} / \mathrm{mo}$, respectively. The lava-rock parameters yielded the highest recharge values; the thick-soil parameters the lowest (tables 6-8).
For thin-soil parameters, calculated monthly recharge ranged from 10 to 29 percent of monthly mean precipitation, and annual recharge ranged from 16 to 23 percent of mean annual precipitation (table 6). For thick-soil parameters, calculated monthly recharge ranged from 1 to 5 percent of monthly mean precipitation, and annual recharge ranged from 2 to 4 percent of mean annual precipitation (table 7). For lava-rock parameters, calculated monthly recharge ranged from 37 to 57 percent of monthly mean precipitation, and annual recharge ranged from 45 to 52 percent of mean annual precipitation (table 8).

Table 4. Mean annual precipitation at active weather stations and calculated Langbein recharge.

[Western Regional Climate Center (2006a, 2006b). Mean precipitation values are through December 31, 2005. A bbreviations: Exp. Stat., experiment station; WSO, Weather Service Office; in., inch; ratio, recharge to precipitation ratio]

\begin{tabular}{llcccccc}
\hline & \multicolumn{9}{c}{ Station name } \\
\cline { 3 - 8 } & & $\begin{array}{c}\text { Bayview } \\
\text { Model } \\
\text { Basin }\end{array}$ & $\begin{array}{c}\text { Coeur } \\
\text { D'Alene 1E }\end{array}$ & Newport & $\begin{array}{c}\text { Priest River } \\
\text { Exp. Stat. }\end{array}$ & $\begin{array}{c}\text { Sandpoint } \\
\text { Exp. Stat. }\end{array}$ & $\begin{array}{c}\text { Spokane } \\
\text { WSO } \\
\text { Airport }\end{array}$ \\
\hline \multirow{2}{*}{ Annual } & Precipitation (in.) & 24 & 25 & 26 & 31 & 32 & 16 \\
& Recharge (in.) & 1.4 & 1.4 & 1.6 & 2.7 & 3.5 & .00 \\
& Ratio (percent) & 6.0 & 6.0 & 6.0 & 9.0 & 11 & 0 \\
\hline
\end{tabular}


Table 5. Mean monthly precipitation at active weather stations and U.S. Department of Agriculture recharge.

[Western Regional Climate Center (2006a, 2006b). Mean precipitation values are through December 31, 2005. A bbreviations: Exp. Stat., experiment station; WSO, Weather Service Office; in., inch; ratio, recharge to precipitation ratio]

\begin{tabular}{|c|c|c|c|c|c|c|c|}
\hline & & \multicolumn{6}{|c|}{ Station name } \\
\hline & & $\begin{array}{l}\text { Bayview } \\
\text { Model } \\
\text { Basin }\end{array}$ & $\begin{array}{c}\text { Coeur } \\
\text { D'Alene 1E }\end{array}$ & Newport & $\begin{array}{c}\text { Priest } \\
\text { River } \\
\text { Exp. Stat. }\end{array}$ & $\begin{array}{l}\text { Sandpoint } \\
\text { Exp. Stat. }\end{array}$ & $\begin{array}{c}\text { Spokane } \\
\text { WSO } \\
\text { Airport }\end{array}$ \\
\hline \multirow{3}{*}{ January } & Precipitation (in.) & 2.8 & 3.4 & 3.2 & 4.0 & 4.1 & 2.0 \\
\hline & Recharge (in.) & 1.9 & 2.3 & 2.2 & 2.8 & 2.8 & 1.3 \\
\hline & Ratio (percent) & 69 & 69 & 69 & 70 & 70 & 68 \\
\hline \multirow{3}{*}{ February } & Precipitation (in.) & 2.1 & 2.5 & 2.4 & 3.0 & 3.1 & 1.5 \\
\hline & Recharge (in.) & 1.5 & 1.7 & 1.6 & 2.0 & 2.2 & 1.0 \\
\hline & Ratio (percent) & 68 & 68 & 68 & 69 & 69 & 67 \\
\hline \multirow[t]{3}{*}{ March } & Precipitation (in.) & 2.0 & 2.3 & 2.3 & 2.7 & 2.8 & 1.4 \\
\hline & Recharge (in.) & 1.4 & 1.5 & 1.5 & 1.9 & 1.9 & .93 \\
\hline & Ratio (percent) & 68 & 68 & 68 & 69 & 69 & 67 \\
\hline \multirow[t]{3}{*}{ April } & Precipitation (in.) & 1.8 & 1.7 & 1.8 & 2.1 & 2.1 & 1.1 \\
\hline & Recharge (in.) & 1.2 & 1.1 & 1.2 & 1.4 & 1.4 & .72 \\
\hline & Ratio (percent) & 66 & 66 & 66 & 68 & 66 & 64 \\
\hline \multirow[t]{3}{*}{ May } & Precipitation (in.) & 2.1 & 2.0 & 2.1 & 2.3 & 2.3 & 1.4 \\
\hline & Recharge (in.) & 1.3 & 1.3 & 1.3 & 1.6 & 1.5 & .87 \\
\hline & Ratio (percent) & 64 & 62 & 63 & 68 & 63 & 61 \\
\hline \multirow[t]{3}{*}{ June } & Precipitation (in.) & 1.8 & 1.8 & 1.9 & 2.3 & 2.3 & 1.2 \\
\hline & Recharge (in.) & 1.1 & 1.0 & 1.1 & 1.5 & 1.4 & .68 \\
\hline & Ratio (percent) & 60 & 58 & 60 & 68 & 60 & 57 \\
\hline \multirow[t]{3}{*}{ July } & Precipitation (in.) & 1.0 & .7 & .9 & 1.0 & 1.0 & .55 \\
\hline & Recharge (in.) & .54 & .38 & .52 & .69 & .54 & .29 \\
\hline & Ratio (percent) & 56 & 53 & 55 & 66 & 55 & 53 \\
\hline \multirow[t]{3}{*}{ August } & Precipitation (in.) & 1.1 & .9 & 1.0 & 1.2 & 1.2 & .63 \\
\hline & Recharge (in.) & .62 & .51 & .57 & .77 & .68 & .35 \\
\hline & Ratio (percent) & 58 & 55 & 58 & 66 & 58 & 56 \\
\hline \multirow[t]{3}{*}{ September } & Precipitation (in.) & 1.2 & 1.3 & 1.4 & 1.6 & 1.7 & .80 \\
\hline & Recharge (in.) & .76 & .79 & .86 & 1.1 & 1.1 & .49 \\
\hline & Ratio (percent) & 63 & 62 & $63^{.00}$ & 67 & 64 & 62 \\
\hline \multirow[t]{3}{*}{ October } & Precipitation (in.) & 2.1 & 2.0 & 2.2 & 2.6 & 2.6 & 1.2 \\
\hline & Recharge (in.) & 1.4 & 1.3 & 1.5 & 1.8 & 1.8 & .76 \\
\hline & Ratio (percent) & 67 & 66 & 68 & 68 & 68 & $65^{.70}$ \\
\hline \multirow[t]{3}{*}{ November } & Precipitation (in.) & 2.9 & 3.1 & 3.5 & 4.0 & 4.3 & 2.1 \\
\hline & Recharge (in.) & 2.0 & 2.1 & 2.4 & 2.8 & 3.1 & 1.4 \\
\hline & Ratio (percent) & 69 & 69 & 70 & 70 & 72 & 68 \\
\hline \multirow[t]{3}{*}{ December } & Precipitation (in.) & 3.2 & 3.6 & 3.7 & 4.4 & 4.6 & 2.2 \\
\hline & Recharge (in.) & 2.2 & 2.5 & 2.6 & 3.2 & 3.3 & 1.5 \\
\hline & Ratio (percent) & 69 & 70 & 70 & 72 & 73 & 68 \\
\hline \multirow[t]{3}{*}{ Annual } & Precipitation (in.) & 24 & 25 & 26 & 31 & 31 & 16 \\
\hline & Recharge (in.) & 16 & 17 & 17 & 22 & 22 & 10 \\
\hline & Ratio (percent) & 66 & 66 & 66 & 69 & 68 & 64 \\
\hline
\end{tabular}


Table 6. Mean monthly precipitation at active weather stations and calculated Eastern Snake Plain Aquifer Model recharge (thin-soil parameters).

[Western Regional Climate Center (2006a, 2006b). Mean precipitation values are through December 31, 2005. Abbreviations: Exp. Stat., experiment station; WSO, Weather Service Office; in., inch; ratio, recharge to precipitation ratio]

\begin{tabular}{|c|c|c|c|c|c|c|c|}
\hline & & \multicolumn{6}{|c|}{ Station name } \\
\hline & & $\begin{array}{c}\text { Bayview } \\
\text { Model } \\
\text { Basin }\end{array}$ & $\begin{array}{c}\text { Coeur } \\
\text { D' Alene } \\
1 E\end{array}$ & Newport & $\begin{array}{c}\text { Priest River } \\
\text { Exp. Stat. }\end{array}$ & $\begin{array}{l}\text { Sandpoint } \\
\text { Exp. Stat. }\end{array}$ & $\begin{array}{c}\text { Spokane } \\
\text { WSO } \\
\text { Airport }\end{array}$ \\
\hline \multirow[t]{3}{*}{ January } & Precipitation (in.) & 2.8 & 3.4 & 3.2 & 4.0 & 4.1 & 2.0 \\
\hline & Recharge (in.) & .64 & .82 & .76 & 1.1 & 1.1 & .37 \\
\hline & Ratio (percent) & 22 & 24 & 24 & 27 & 27 & 19 \\
\hline \multirow[t]{3}{*}{ February } & Precipitation (in.) & 2.1 & 2.5 & 2.4 & 3.0 & 3.1 & 1.5 \\
\hline & Recharge (in.) & .42 & .51 & .48 & .68 & .74 & .26 \\
\hline & Ratio (percent) & 20 & 21 & 20 & 23 & 24 & 17 \\
\hline \multirow[t]{3}{*}{ March } & Precipitation (in.) & 2.0 & 2.3 & 2.3 & 2.7 & 2.8 & 1.4 \\
\hline & Recharge (in.) & .39 & .46 & .46 & .60 & .61 & .22 \\
\hline & Ratio (percent) & 19 & 20 & 20 & 22 & 22 & 16 \\
\hline \multirow[t]{3}{*}{ April } & Precipitation (in.) & 1.8 & 1.7 & 1.8 & 2.1 & 2.1 & 1.1 \\
\hline & Recharge (in.) & .31 & .30 & .33 & .40 & .40 & .16 \\
\hline & Ratio (percent) & 18 & 18 & 18 & 19 & 19 & 14 \\
\hline \multirow[t]{3}{*}{ May } & Precipitation (in.) & 2.1 & 2.0 & 2.1 & 2.3 & 2.3 & 1.4 \\
\hline & Recharge (in.) & .40 & .38 & .40 & .48 & .48 & .23 \\
\hline & Ratio (percent) & 19 & 19 & 19 & 20 & 20 & 16 \\
\hline \multirow[t]{3}{*}{ June } & Precipitation (in.) & 1.8 & 1.8 & 1.9 & 2.3 & 2.3 & 1.2 \\
\hline & Recharge (in.) & .32 & .32 & .34 & .45 & .45 & .18 \\
\hline & Ratio (percent) & 18 & 18 & 18 & 20 & 20 & 15 \\
\hline \multirow[t]{3}{*}{ July } & Precipitation (in.) & 1.0 & .7 & .9 & 1.0 & 1.0 & .55 \\
\hline & Recharge (in.) & .13 & .08 & .12 & .14 & .13 & .05 \\
\hline & Ratio (percent) & 13 & 11 & 13 & 14 & 13 & 10 \\
\hline \multirow[t]{3}{*}{ August } & Precipitation (in) & 1.1 & .9 & 1.0 & 1.2 & 1.2 & .63 \\
\hline & Recharge (in) & .15 & .12 & .13 & .17 & .17 & .07 \\
\hline & Ratio (percent) & 14 & 13 & 13 & 14 & 15 & 11 \\
\hline \multirow[t]{3}{*}{ September } & Precipitation (in.) & 1.2 & 1.3 & 1.4 & 1.6 & 1.7 & .80 \\
\hline & Recharge (in.) & .18 & .19 & .21 & .26 & .29 & .10 \\
\hline & Ratio (percent) & 15 & 15 & 16 & 17 & 17 & 12 \\
\hline \multirow[t]{3}{*}{ October } & Precipitation (in.) & 2.1 & 2.0 & 2.2 & 2.6 & 2.6 & 1.2 \\
\hline & Recharge (in.) & .40 & .37 & .43 & .55 & .57 & .17 \\
\hline & Ratio (percent) & 19 & 19 & 20 & 21 & 22 & 14 \\
\hline \multirow[t]{3}{*}{ November } & Precipitation (in.) & 2.9 & 3.1 & 3.5 & 4.0 & 4.3 & 2.1 \\
\hline & Recharge (in.) & .67 & .73 & .86 & 1.1 & 1.2 & .40 \\
\hline & Ratio (percent) & 23 & 23 & 25 & 27 & 28 & 19 \\
\hline \multirow[t]{3}{*}{ December } & Precipitation (in.) & 3.2 & 3.6 & 3.7 & 4.4 & 4.6 & 2.2 \\
\hline & Recharge (in.) & .75 & .92 & .95 & 1.2 & 1.3 & .43 \\
\hline & Ratio (percent) & 24 & 25 & 26 & 28 & 29 & 20 \\
\hline \multirow[t]{3}{*}{ Annual } & Precipitation (in.) & 24.1 & 25.2 & 26.2 & 31.1 & 32.0 & 16.1 \\
\hline & Recharge (in.) & 4.7 & 5.2 & 5.5 & 7.1 & 7.4 & 2.6 \\
\hline & Ratio (percent) & 20 & 21 & 21 & 23 & 23 & 16 \\
\hline
\end{tabular}


Table 7. Mean monthly precipitation at active weather stations and calculated Eastern Snake Plain Aquifer Model recharge (thick-soil parameters).

[Western Regional Climate Center (2006a, 2006b). Mean precipitation values are through December 31, 2005. Exp. Stat., experiment station; WSO, Weather Service Office; in., inch; ratio, recharge to precipitation ratio]

\begin{tabular}{|c|c|c|c|c|c|c|c|}
\hline & & \multicolumn{6}{|c|}{ Station name } \\
\hline & & $\begin{array}{c}\text { Bayview } \\
\text { Model } \\
\text { Basin }\end{array}$ & $\begin{array}{c}\text { Coeur } \\
\text { D'Alene 1E }\end{array}$ & Newport & $\begin{array}{c}\text { Priest } \\
\text { River Exp. } \\
\text { Stat. }\end{array}$ & $\begin{array}{l}\text { Sandpoint } \\
\text { Exp. Stat. }\end{array}$ & $\begin{array}{c}\text { Spokane } \\
\text { WSO } \\
\text { Airport }\end{array}$ \\
\hline \multirow[t]{3}{*}{ January } & Precipitation (in.) & 2.8 & 3.4 & 3.2 & 4.0 & 4.1 & 2.0 \\
\hline & Recharge (in.) & .09 & .13 & .11 & .18 & .19 & .04 \\
\hline & Ratio (percent) & 3 & 4 & 4 & 5 & 5 & 2 \\
\hline \multirow[t]{3}{*}{ February } & Precipitation (in.) & 2.1 & 2.5 & 2.4 & 3.0 & 3.1 & 1.5 \\
\hline & Recharge (in.) & .05 & .07 & .06 & .01 & .11 & .03 \\
\hline & Ratio (percent) & 2 & 3 & 3 & 3 & 4 & 2 \\
\hline \multirow[t]{3}{*}{ March } & Precipitation (in.) & 2.0 & 2.3 & 2.3 & 2.7 & 2.8 & 1.4 \\
\hline & Recharge (in.) & .05 & .06 & .06 & .08 & .09 & .02 \\
\hline & Ratio (percent) & 2 & 3 & 3 & 3 & 3 & 2 \\
\hline \multirow[t]{3}{*}{ April } & Precipitation (in.) & 1.8 & 1.7 & 1.8 & 2.1 & 2.1 & 1.1 \\
\hline & Recharge (in.) & .03 & .03 & .04 & .05 & .05 & .01 \\
\hline & Ratio (percent) & 2 & 2 & 2 & 2 & 2 & 1 \\
\hline \multirow[t]{3}{*}{ May } & Precipitation (in.) & 2.1 & 2.0 & 2.1 & 2.3 & 2.3 & 1.4 \\
\hline & Recharge (in.) & .05 & .05 & .05 & .06 & .06 & .02 \\
\hline & Ratio (percent) & 2 & 2 & 2 & 3 & 3 & 2 \\
\hline \multirow[t]{3}{*}{ June } & Precipitation (in.) & 1.8 & 1.8 & 1.9 & 2.3 & 2.3 & 1.2 \\
\hline & Recharge (in.) & .04 & .04 & .04 & .06 & .06 & .02 \\
\hline & Ratio (percent) & 2 & 2 & 2 & 3 & 3 & 1 \\
\hline \multirow[t]{3}{*}{ July } & Precipitation (in.) & 1.0 & .7 & .9 & 1.0 & 1.0 & .55 \\
\hline & Recharge (in.) & .01 & .01 & .09 & .01 & .01 & .00 \\
\hline & Ratio (percent) & 1 & 1 & 1 & 1 & 1 & 1 \\
\hline \multirow[t]{3}{*}{ August } & Precipitation (in.) & 1.1 & .9 & 1.0 & 1.2 & 1.2 & .63 \\
\hline & Recharge (in.) & .01 & .01 & .01 & .02 & .02 & .00 \\
\hline & Ratio (percent) & 1 & 1 & 1 & 1 & 1 & 1 \\
\hline \multirow[t]{3}{*}{ September } & Precipitation (in.) & 1.2 & 1.3 & 1.4 & 1.6 & 1.7 & .80 \\
\hline & Recharge (in.) & .02 & .02 & .02 & .03 & .03 & .01 \\
\hline & Ratio (percent) & 1 & 1 & 2 & 2 & 2 & 1 \\
\hline \multirow[t]{3}{*}{ October } & Precipitation (in.) & 2.1 & 2.0 & 2.2 & 2.6 & 2.6 & 1.2 \\
\hline & Recharge (in.) & .05 & .04 & .05 & .07 & .08 & .02 \\
\hline & Ratio (percent) & 2 & 2 & 2 & 3 & 3 & 1 \\
\hline \multirow[t]{3}{*}{ November } & Precipitation (in.) & 2.9 & 3.1 & 3.5 & 4.0 & 4.3 & 2.1 \\
\hline & Recharge (in.) & .10 & .11 & .14 & .18 & .21 & .05 \\
\hline & Ratio (percent) & 3 & 4 & 4 & 5 & 5 & 2 \\
\hline \multirow[t]{3}{*}{ December } & Precipitation (in.) & 3.2 & 3.6 & 3.7 & 4.4 & 4.6 & 2.2 \\
\hline & Recharge (in.) & .11 & .15 & .16 & .22 & .24 & .05 \\
\hline & Ratio (percent) & 4 & 4 & 4 & 5 & 5 & 2 \\
\hline \multirow[t]{3}{*}{ Annual } & Precipitation (in.) & 24 & 25 & 26 & 31 & 32 & 16 \\
\hline & Recharge (in.) & .61 & .71 & .75 & 1.1 & 1.13 & .28 \\
\hline & Ratio (percent) & 3 & 3 & 3 & 3 & 4 & 2 \\
\hline
\end{tabular}


Table 8. Mean monthly precipitation at active weather stations and calculated Eastern Snake Plain Aquifer Model recharge (lava-rock parameters).

[Western Regional Climate Center (2006a, 2006b). Mean precipitation values are through December 31, 2005. A bbreviations: Exp. Stat., experiment station; WSO, Weather Service Office; in., inch; ratio, recharge to precipitation ratio]

\begin{tabular}{|c|c|c|c|c|c|c|c|}
\hline & & \multicolumn{6}{|c|}{ Station name } \\
\hline & & $\begin{array}{c}\text { Bayview } \\
\text { Model } \\
\text { Basin }\end{array}$ & $\begin{array}{c}\text { Coeur } \\
\text { D'Alene } \\
1 E\end{array}$ & Newport & $\begin{array}{c}\text { Priest River } \\
\text { Exp. Stat. }\end{array}$ & $\begin{array}{l}\text { Sandpoint } \\
\text { Exp. Stat. }\end{array}$ & $\begin{array}{c}\text { Spokane } \\
\text { WSO } \\
\text { Airport }\end{array}$ \\
\hline \multirow[t]{3}{*}{ January } & Precipitation (in.) & 2.8 & 3.4 & 3.2 & 4.0 & 4.1 & 2.0 \\
\hline & Recharge (in.) & 1.5 & 1.8 & 1.7 & 2.2 & 2.3 & .95 \\
\hline & Ratio (percent) & 52 & 53 & 53 & 55 & 56 & 48 \\
\hline \multirow[t]{3}{*}{ February } & Precipitation (in.) & 2.1 & 2.5 & 2.4 & 3.0 & 3.1 & 1.5 \\
\hline & Recharge (in.) & 1.0 & 1.2 & 1.2 & 1.5 & 1.7 & .70 \\
\hline & Ratio (percent) & 49 & 50 & 50 & 52 & 53 & 46 \\
\hline \multirow[t]{3}{*}{ March } & Precipitation (in.) & 2.0 & 2.3 & 2.3 & 2.7 & 2.8 & 1.4 \\
\hline & Recharge (in.) & .99 & 1.13 & 1.13 & 1.39 & 1.42 & .62 \\
\hline & Ratio (percent) & 48 & 49 & 49 & 51 & 51 & 45 \\
\hline \multirow[t]{3}{*}{ April } & Precipitation (in.) & 1.8 & 1.7 & 1.8 & 2.1 & 2.1 & 1.1 \\
\hline & Recharge (in.) & .82 & .81 & .86 & 1.02 & 1.01 & .48 \\
\hline & Ratio (percent) & 47 & 47 & 47 & 49 & 49 & 43 \\
\hline \multirow[t]{3}{*}{ May } & Precipitation (in.) & 2.1 & 2.0 & 2.1 & 2.3 & 2.3 & 1.4 \\
\hline & Recharge (in.) & 1.0 & .97 & 1.0 & 1.2 & 1.2 & .64 \\
\hline & Ratio (percent) & 49 & 48 & 49 & 50 & 50 & 45 \\
\hline \multirow[t]{3}{*}{ June } & Precipitation (in.) & 1.8 & 1.8 & 1.9 & 2.3 & 2.3 & 1.2 \\
\hline & Recharge (in.) & .85 & .85 & 0.88 & 1.12 & 1.12 & .52 \\
\hline & Ratio (percent) & 47 & 47 & 48 & 49 & 49 & 44 \\
\hline \multirow[t]{3}{*}{ July } & Precipitation (in.) & 1.0 & .7 & .9 & 1.0 & 1.0 & .55 \\
\hline & Recharge (in.) & .41 & .28 & .38 & .44 & .41 & .20 \\
\hline & Ratio (percent) & 42 & 39 & 41 & 42 & 42 & 37 \\
\hline \multirow[t]{3}{*}{ August } & Precipitation (in.) & 1.1 & .9 & 1.0 & 1.2 & 1.2 & .63 \\
\hline & Recharge (in.) & .46 & .38 & .41 & .50 & .51 & .24 \\
\hline & Ratio (percent) & 43 & 41 & 42 & 43 & 43 & 38 \\
\hline \multirow[t]{3}{*}{ September } & Precipitation (in.) & 1.2 & 1.3 & 1.4 & 1.6 & 1.7 & .80 \\
\hline & Recharge (in.) & .53 & .56 & .61 & .72 & .79 & .32 \\
\hline & Ratio (percent) & 44 & 44 & 45 & 46 & 47 & 40 \\
\hline \multirow[t]{3}{*}{ October } & Precipitation (in.) & 2.1 & 2.0 & 2.2 & 2.6 & 2.6 & 1.2 \\
\hline & Recharge (in.) & 1.0 & .95 & 1.1 & 1.3 & 1.3 & .51 \\
\hline & Ratio (percent) & 49 & 48 & 49 & 51 & 51 & 43 \\
\hline \multirow[t]{3}{*}{ November } & Precipitation (in.) & 2.9 & 3.1 & 3.5 & 4.0 & 4.3 & 2.1 \\
\hline & Recharge (in.) & 1.5 & 1.6 & 1.9 & 2.2 & 2.4 & 1.0 \\
\hline & Ratio (percent) & 52 & 53 & 54 & 55 & 56 & 49 \\
\hline \multirow[t]{3}{*}{ December } & Precipitation (in.) & 3.2 & 3.6 & 3.7 & 4.4 & 4.6 & 2.2 \\
\hline & Recharge (in.) & 1.7 & 2.0 & 2.0 & 2.5 & 2.6 & 1.1 \\
\hline & Ratio (percent) & 53 & 54 & 55 & 56 & 57 & 49 \\
\hline \multirow[t]{3}{*}{ Annual } & Precipitation (in.) & 24 & 25 & 26 & 31 & 32 & 16 \\
\hline & Recharge (in.) & 12 & 13 & 13 & 16 & 17 & 7.3 \\
\hline & Ratio (percent) & 49 & 50 & 50 & 52 & 52 & 45 \\
\hline
\end{tabular}


For a given precipitation $(P)$, paired slope parameter $(K)$, and coefficient for curvature $(N)$, recharge calculated by the ESPAM method will be equivalent to that calculated for the ESRP. It is difficult to evaluate the validity of this assumption: although the lowest values of mean annual precipitation on the ESRP are approximately one-half of those in the SVRP aquifer area, mean annual maximum temperatures at higher elevation stations on the ESRP are similar to those in the area of the SVRP aquifer. The range of March-October potential evapotranspiration values for the ESRP range from 46.5 to 57.4 in.; for the Bayview Model Basin, Sandpoint Experiment Station, and Coeur D'Alene 1E weather stations, the values are 39.1, 40.3, and 42.8 in., respectively (Allen and Brockaway, 1983).

The meteorological data needed for calculation of recharge using the single- or dual-coefficient FAO PenmanMonteith methods are available for only one station in the area-Spokane WSO Airport. Initially, to determine mean monthly recharge with the single-coefficient FAO PenmanMonteith method, the $15^{\text {th }}$ day of each month was used to calculate the relevant radiation parameters for reference evapotranspiration $\left(E T_{o}\right)$ (except percentage of possible sunshine, for which the monthly mean was used). This value was then used with mean monthly meteorological data to obtain mean monthly recharge. Crop evapotranspiration $\left(E T_{c}\right)$, was calculated for grass pasture: development stages for grass pasture $\left(L_{i n i}, L_{d e v}\right.$, and $\left.L_{\text {late }}\right)$ and time-averaged crop coefficients for rotated grazing pasture $\left(K_{c \text { ini }}, K_{c \text { dev }}, K_{c \text { late }}\right.$, and maximum crop height) were taken from tables 11 and 12 , respectively, in Allen and others (1998). The grass-referenced $E T_{c}$ was converted to alfalfa-referenced $E T_{c}$ using the Kimberly, Idaho, conversion factor of 1.24 (Allen and others, 1998). Mean monthly recharge was then calculated by subtracting the mean monthly $E T_{c}$ from mean monthly precipitation. Mean monthly recharge values for both grass- and alfalfa-referenced calculations are shown in table 9.

For grass-referenced calculations, calculated mean monthly recharge ranged from 0 to 81 percent of mean monthly precipitation, and mean annual recharge was 21 percent of mean annual precipitation; for alfalfa- referenced calculations, calculated mean monthly recharge ranged from 0 to 85 percent of mean monthly precipitation, and mean annual recharge was 24 percent of mean annual precipitation (table 9). The most striking feature of these results from the single-coefficient FAO Penman-Monteith equations with mean monthly values is that calculated mean monthly recharge drops to zero during the eight warmest and driest months of the year (March-October). Such a result seems unlikely based on ground-water levels.
Table 9. Mean monthly precipitation at active weather stations and single-coefficient FAO Penman-Monteith recharge, Spokane WSO Airport, Washington.

[Western Regional Climate Center (2006a, 2006b). Mean precipitation values are through December 31, 2005. A bbreviations: Exp. Stat., experiment station; WSO, Weather Service Office; in., inch; ratio, recharge to precipitation ratio]

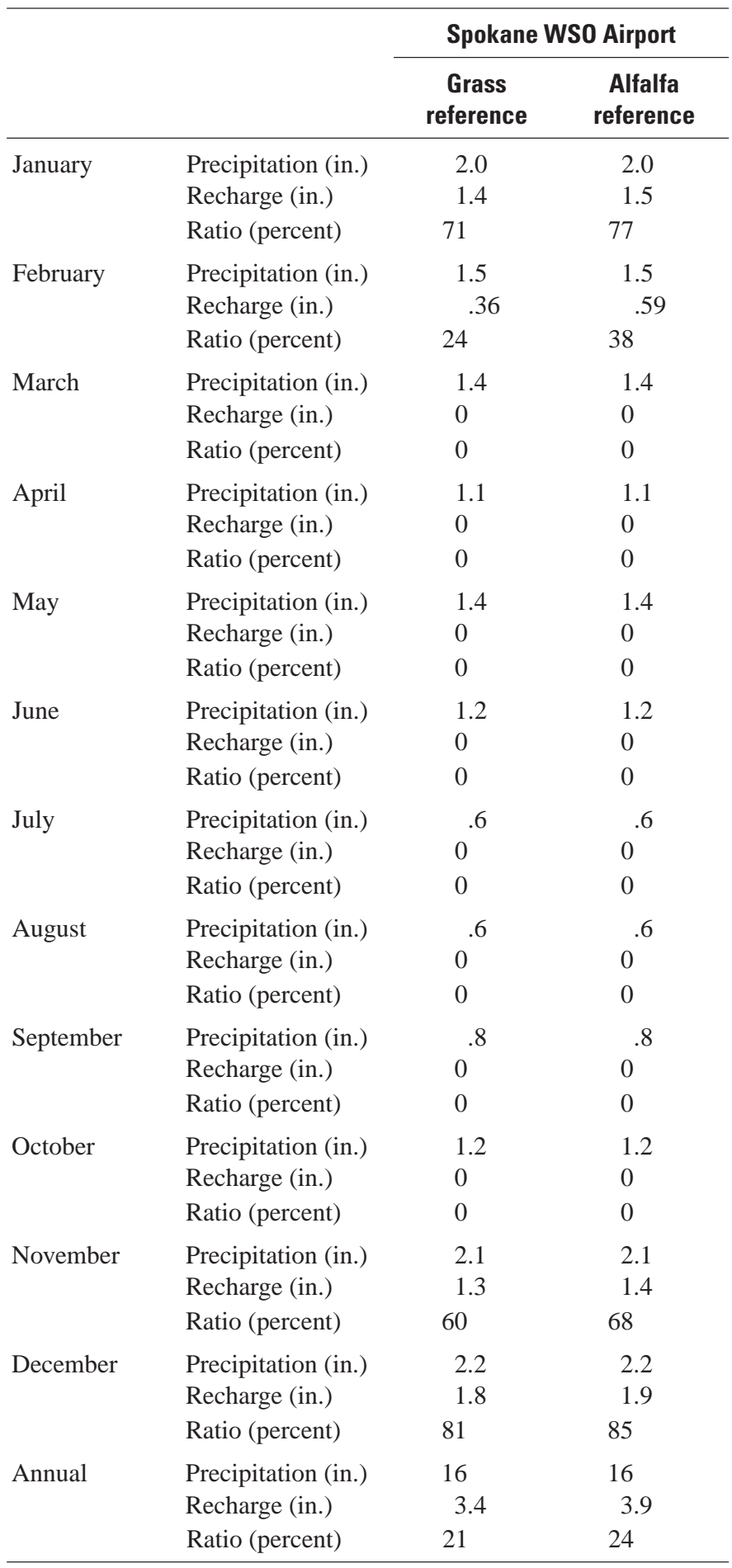


The relations of mean monthly precipitation at each weather station to mean monthly recharge values calculated by the USDA and ESPAM methods are shown in figure 3 . For all stations, the lava-rock parameters yield the highest values of recharge and the thick-soil parameters the lowest among the ESPAM techniques. USDA recharge values are greater than any ESPAM values for all months. For the Spokane WSO Airport station, the single-coefficient FAO Penman-Monteith mean monthly recharge values are highest in the winter and lowest during the growing season.

\section{Daily Recharge, 1990-2005}

As mentioned in the previous section, independent evidence does not support the calculated result of no recharge during the eight warmest and driest months of the year (March-September) and suggests that the single-coefficient FAO Penman-Monteith recharge using mean monthly data does not adequately represent changes in soil-moisture storage. A similar conclusion was reached by Kafri and Ben Asher (1978) in a southern Arizona study, in which they noted, "The conventional approach of calculating recharge by subtracting long-term averages of runoff and evapotranspiration from the total rainfall results in no apparent recharge. This result does not agree with observations of ground-water flows in the corresponding basins."

Such anomalous results from calculations with monthly means may result from the assumption that there is always sufficient soil moisture to satisfy evapotranspiration. However, daily soil-moisture will occasionally be insufficient to meet crop evapotranspiration ( $\left.E T_{c}\right)$ demand, resulting in actual evapotranspiration being less than the calculated $E T_{c}$ value. Thus, recharge depends on the amount and timing of individual precipitation events to replenish soil moisture and exceed $E T_{c}$, allowing deep percolation (assumed to be recharge) through the root zone.

In order to calculate a more realistic value of recharge, the dual-coefficient FAO Penman-Monteith dual-crop evapotranspiration $\left(E T_{c d}\right)$ and deep percolation calculations in equations 18 and 19 were applied to daily values from the Spokane WSO Airport for January 1990 through December 2005. Recorded "trace" values of precipitation were assigned a value of 0.01 in. for daily calculations (although actual trace amounts were between 0.00 and 0.01 in.). As above, crop evapotranspiration $\left(E T_{c}\right)$ was calculated for grass pasture: development stages and time-averaged crop coefficients were taken from tables 11 and 12, respectively, in Allen and others (1998). The key soil characteristics used were a maximum root depth of $0.8 \mathrm{~m}$ and an available water capacity (AWC) of $30 \mathrm{~mm} / \mathrm{m}$. The resultant monthly totals in table 10 show a temporal variability that is absent from the mean monthly values in table 9, and demonstrate that the daily amount and timing of precipitation dramatically affect calculated recharge. Daily values of precipitation and dual-coefficient FAO

Penman-Monteith recharge for the Spokane station are shown in figure 4.

For a given month, there is little consistency between the amount of precipitation and recharge from year to year. The examination of daily values for such "anomalous" months as March 1993, when precipitation was near normal yet no recharge occurred, show a soil-moisture deficit early in the month that needed replenishment by daily precipitation later in the month before deep percolation could occur. Furthermore, significant precipitation on a given day can paradoxically result in calculated value of deep percolation for the following day being greater than precipitation as a result of soil-moisture storage.

Because the daily dual-coefficient FAO PenmanMonteith recharge better represents natural processes than do the mean monthly techniques discussed previously, daily calculations were made for the five remaining weather stations. Unfortunately, the required meteorological data for these stations is limited to maximum and minimum daily temperature and precipitation. To calculate recharge for these stations, two main assumptions were made: (1) wind-speed values for Spokane WSO Airport were used for all weather stations, and (2) dewpoint temperatures were assumed to equal the daily minimum temperature. As with Spokane WSO Airport, trace amounts of precipitation were assigned a value of $0.01 \mathrm{in}$. Missing precipitation values of six or fewer days were assumed to equal zero. Missing temperature values of six or fewer consecutive days were interpolated. For longer periods of missing data, values for a station were assumed to equal those at a station with similar mean values: (1) data from the Priest River Experiment Station were used for Newport from December 1995 through January 1996, and (2) data from Newport were used for Bayview Model Basin for February 1992, March-April 2004, and July 2005. Because the Coeur d'Alene 1E station was missing a substantial amount of data (January 1990 through October 1995, March 1996, March 1998, February 2004, April 2004, June 2005, and November 2005) deep percolation for these periods was not calculated. Monthly summaries for these five weather stations, 19902005, are shown in tables 11-15. Daily values of precipitation and dual-coefficient FAO Penman-Monteith recharge, 19902005, are shown in figures 5-9. The occasional days with large amounts of precipitation (and correspondingly high recharge) are very noticeable on these graphs. In areas with a thin unsaturated zone such events may be reflected in ground-water levels, however, for much of the area, processes in a thick unsaturated zone probably dampen these events into a fairly constant recharge rate. 


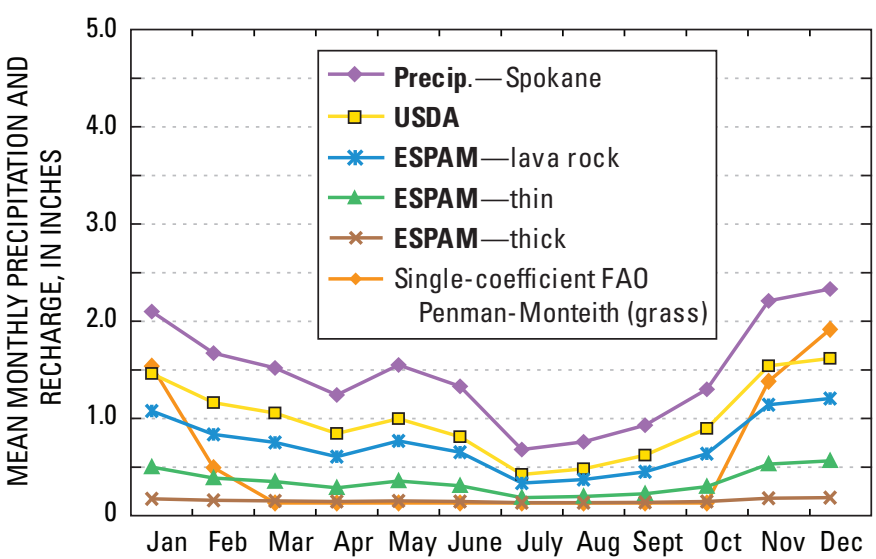

A. Spokane WSO Airport, Washington

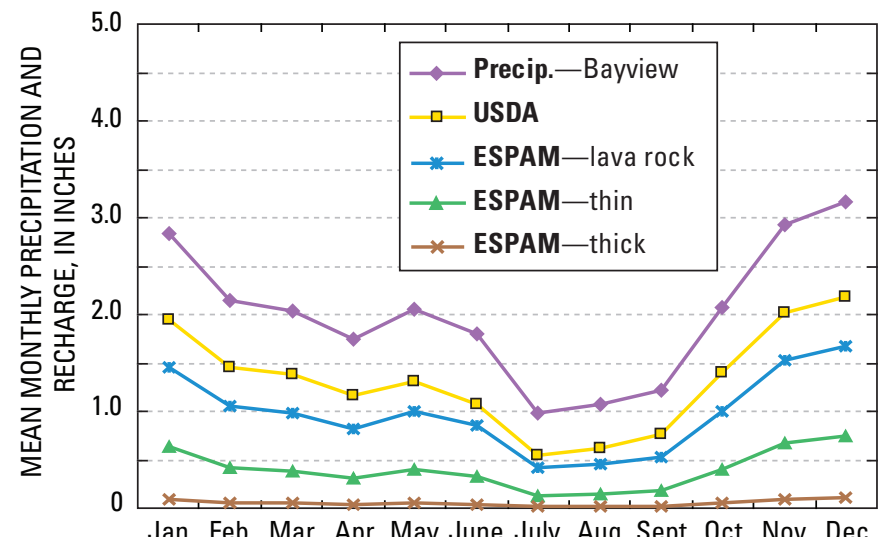

B. Bayview Model Basin, Idaho

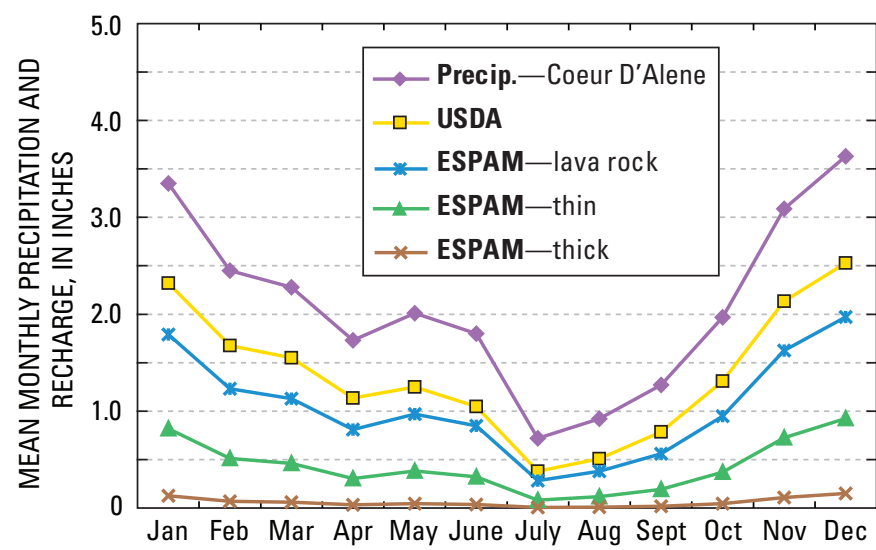

C. Coeur D'Alene $1 \mathrm{E}$, Idaho

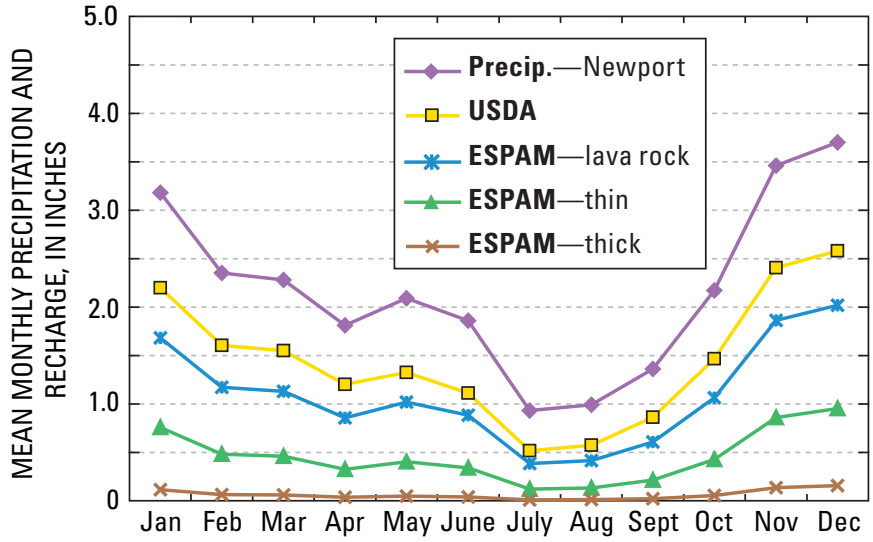

D. Newport, Washington

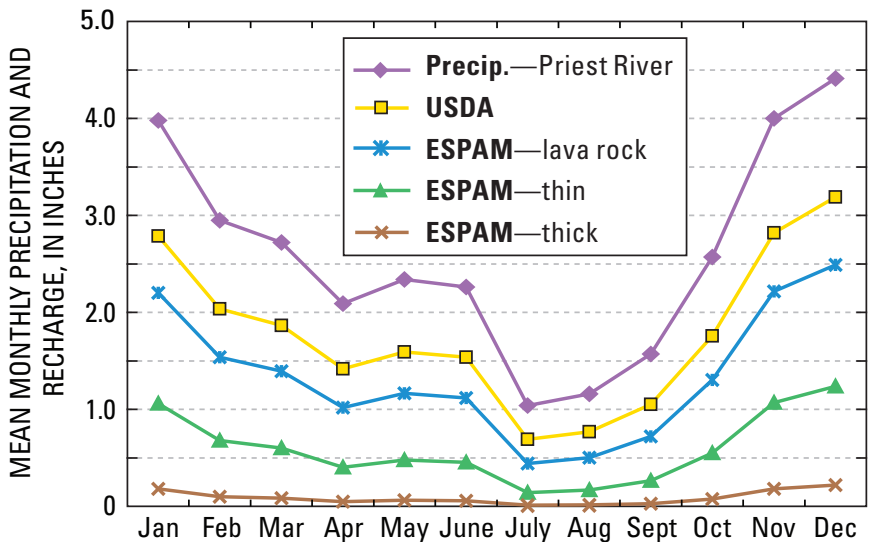

E. Priest River Experiment Station, Idaho

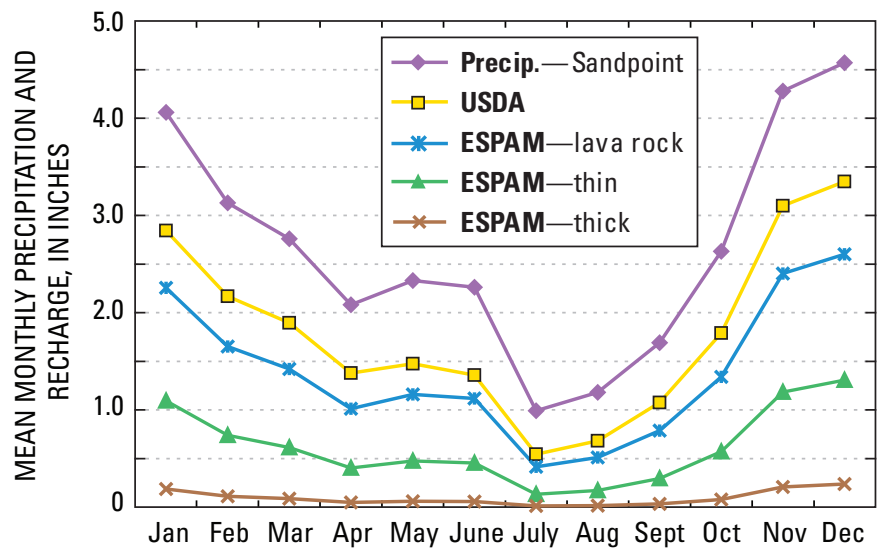

F. Sandpoint Experiment Station, Idaho

Figure 3. Mean monthly precipitation and recharge at each weather station, Idaho and Washington. 
Table 10. Monthly precipitation and dual-coefficient FAO Penman-Monteith recharge using daily values, 1995-2005, Spokane WSO Airport, Washington.

[Western Regional Climate Center (2006a, 2006b), U.S. Department of Commerce (2006). Mean precipitation values are through December $31,2005$. A bbreviations: in., inch; ratio, recharge to precipitation ratio]

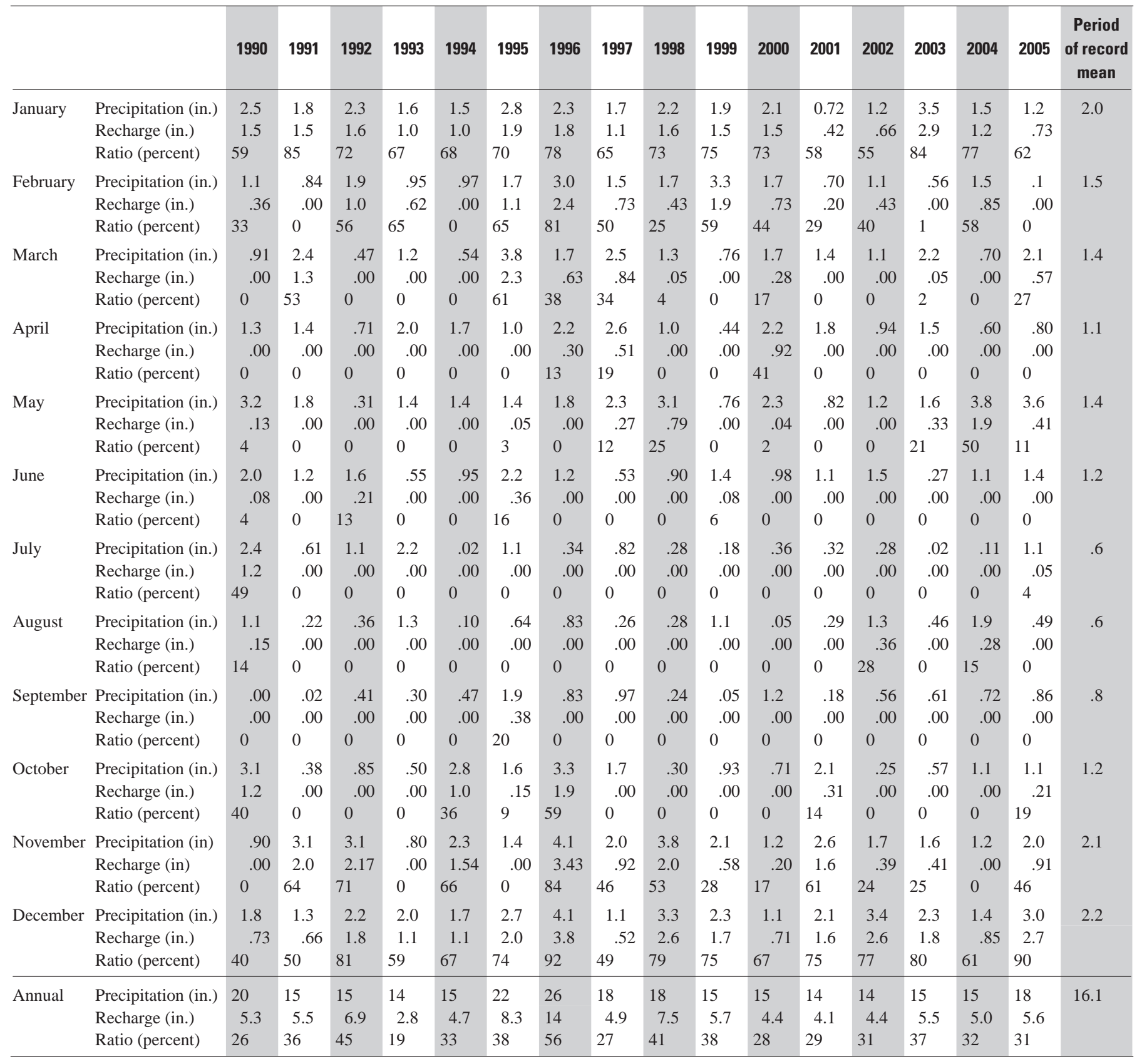



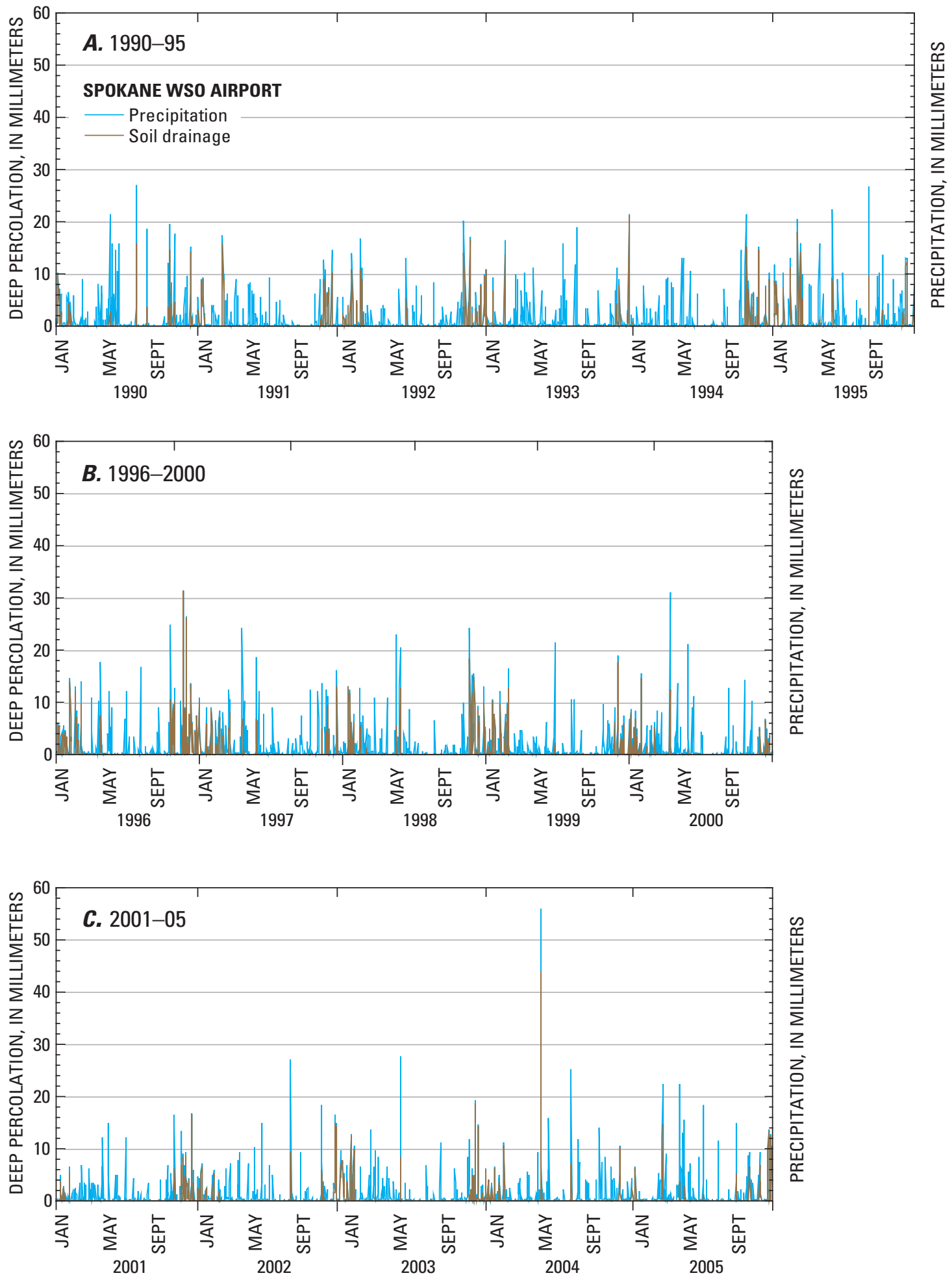

Figure 4. Daily values of precipitation and dual-coefficient FAO Penman-Monteith deep percolation, 1990-2005, Spokane WSO Airport, Washington. 
Table 11. Monthly precipitation and dual-coefficient FAO Penman-Monteith recharge using daily values, 1995-2005, Bayview Model Basin, Idaho.

[Western Regional Climate Center (2006a, 2006b), U.S. Department of Commerce (2006). Mean precipitation values are through December $31,2005$. Abbreviations: in., inch; ratio, recharge to precipitation ratio]

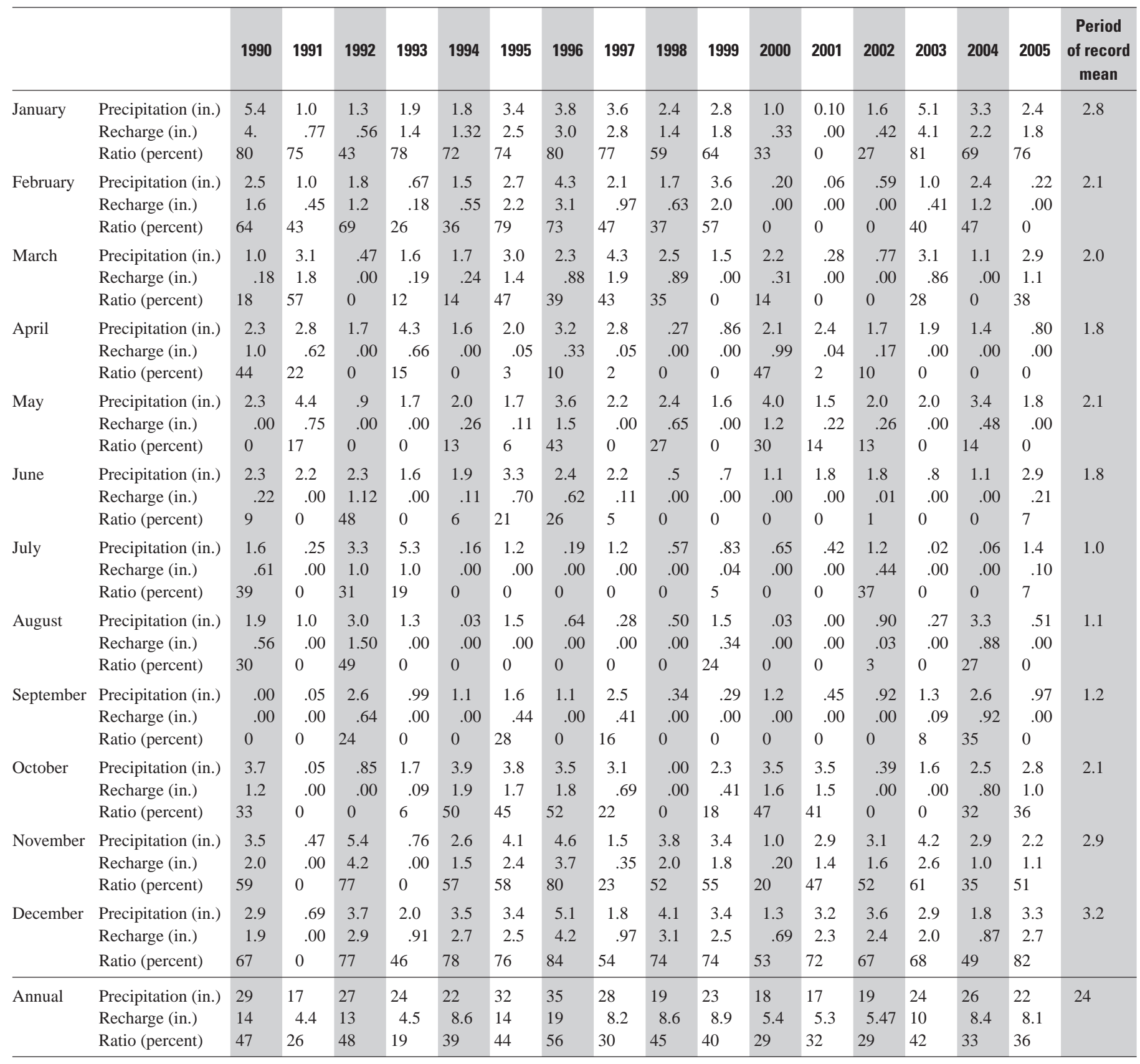


Table 12. Monthly precipitation and dual-coefficient FAO Penman-Monteith recharge using daily values, 1995-2005, Coeur D'Alene 1E, Idaho.

[Western Regional Climate Center (2006a, 2006b), U.S. Department of Commerce (2006). Mean precipitation values are through December 31 , 2005. A bbreviations: in., inch; ratio, recharge to precipitation ratio; -, missing data or value not calculated]

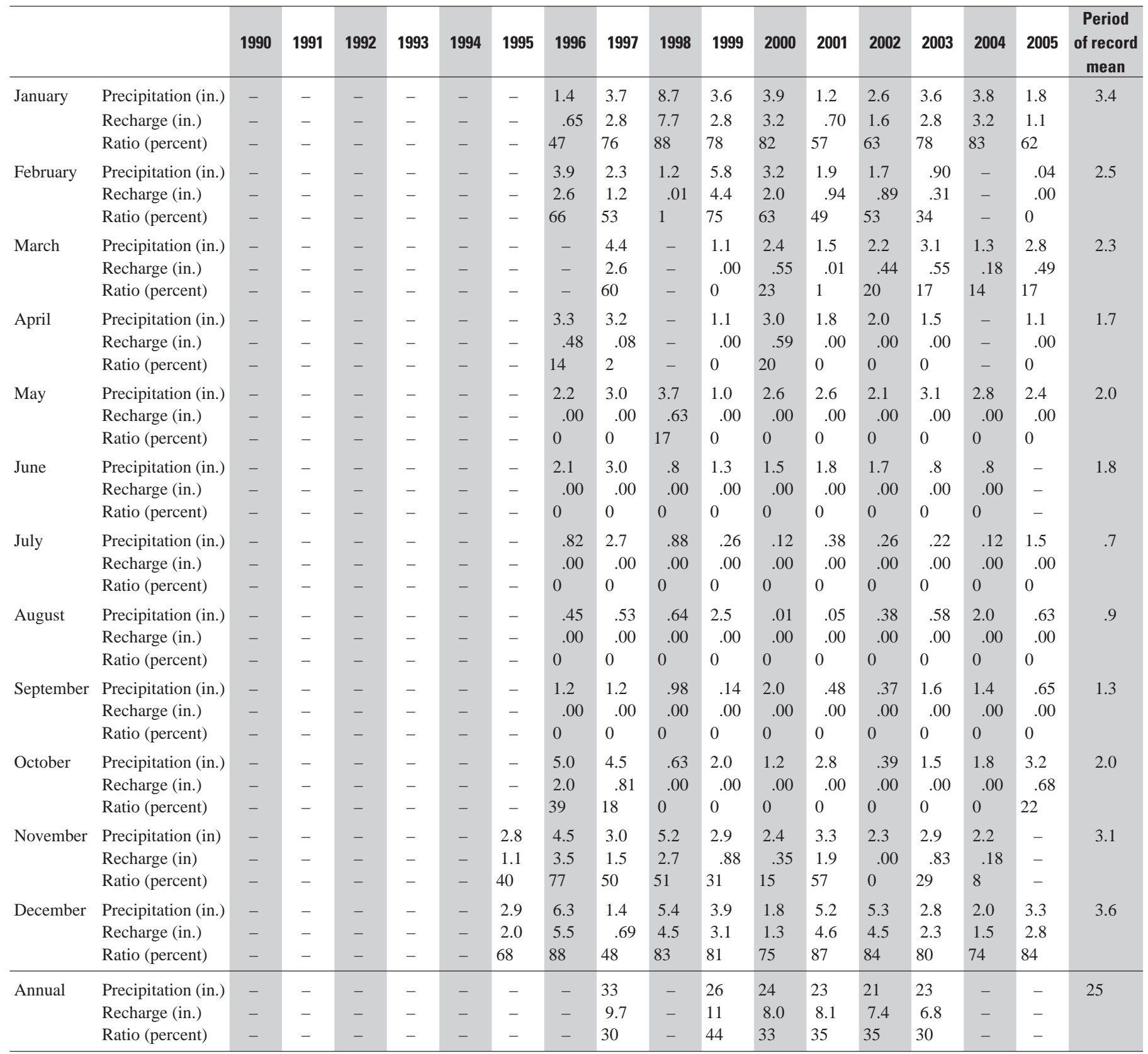


Table 13. Monthly precipitation and dual-coefficient FAO Penman-Monteith recharge using daily values, 1995-2005, Newport, Washington.

[Western Regional Climate Center (2006a, 2006b), U.S. Department of Commerce (2006). Mean precipitation values are through December 31 , 2005. Abbreviations: in., inch; ratio, recharge to precipitation ratio]

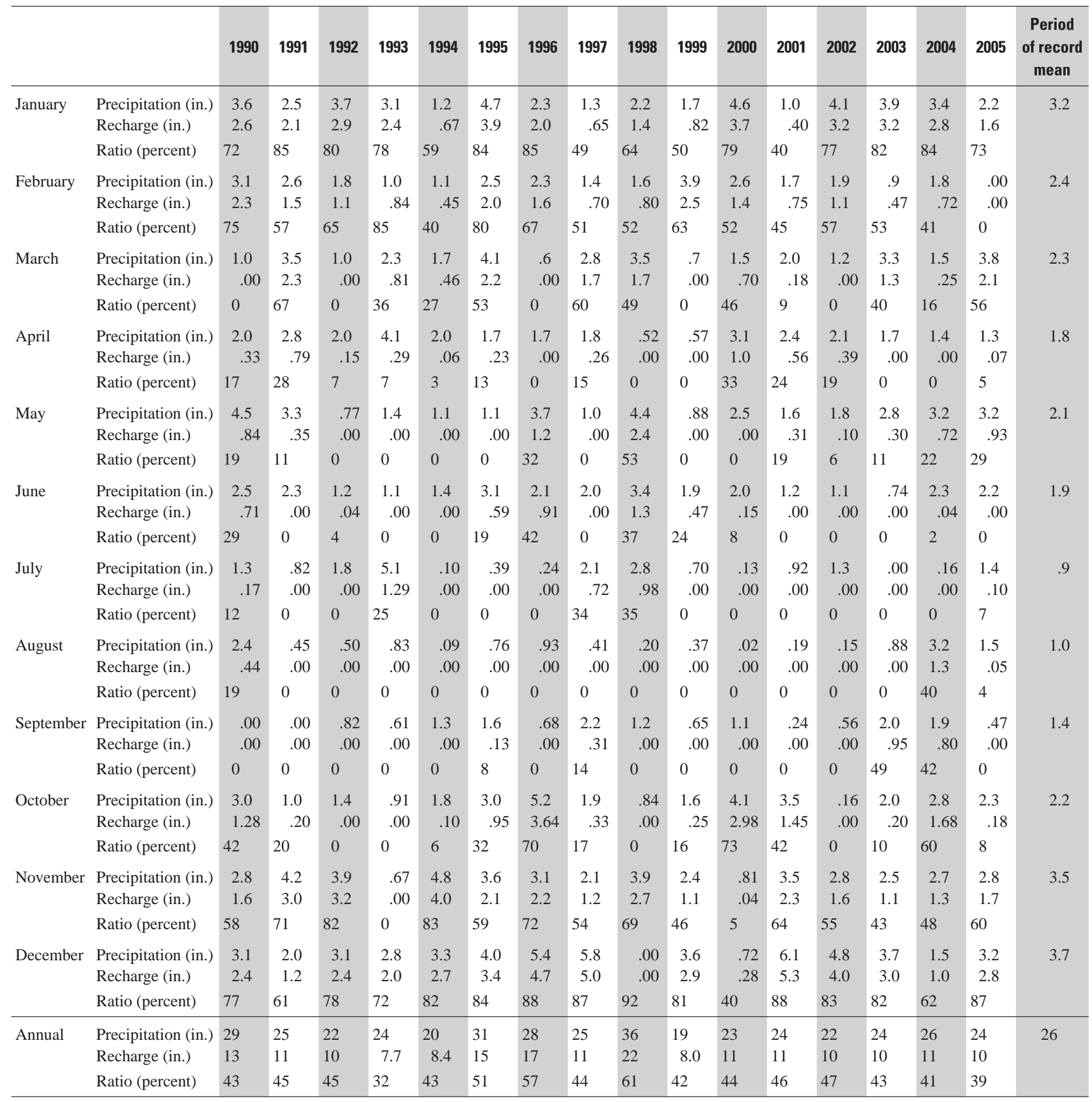


Table 14. Monthly precipitation and dual-coefficient FAO Penman-Monteith recharge using daily values, 1995-2005, Priest River Experiment Station, Idaho.

[Western Regional Climate Center (2006a, 2006b), U.S. Department of Commerce (2006). Mean precipitation values are through December $31,2005$. A bbreviations: in., inch; ratio, recharge to precipitation ratio]

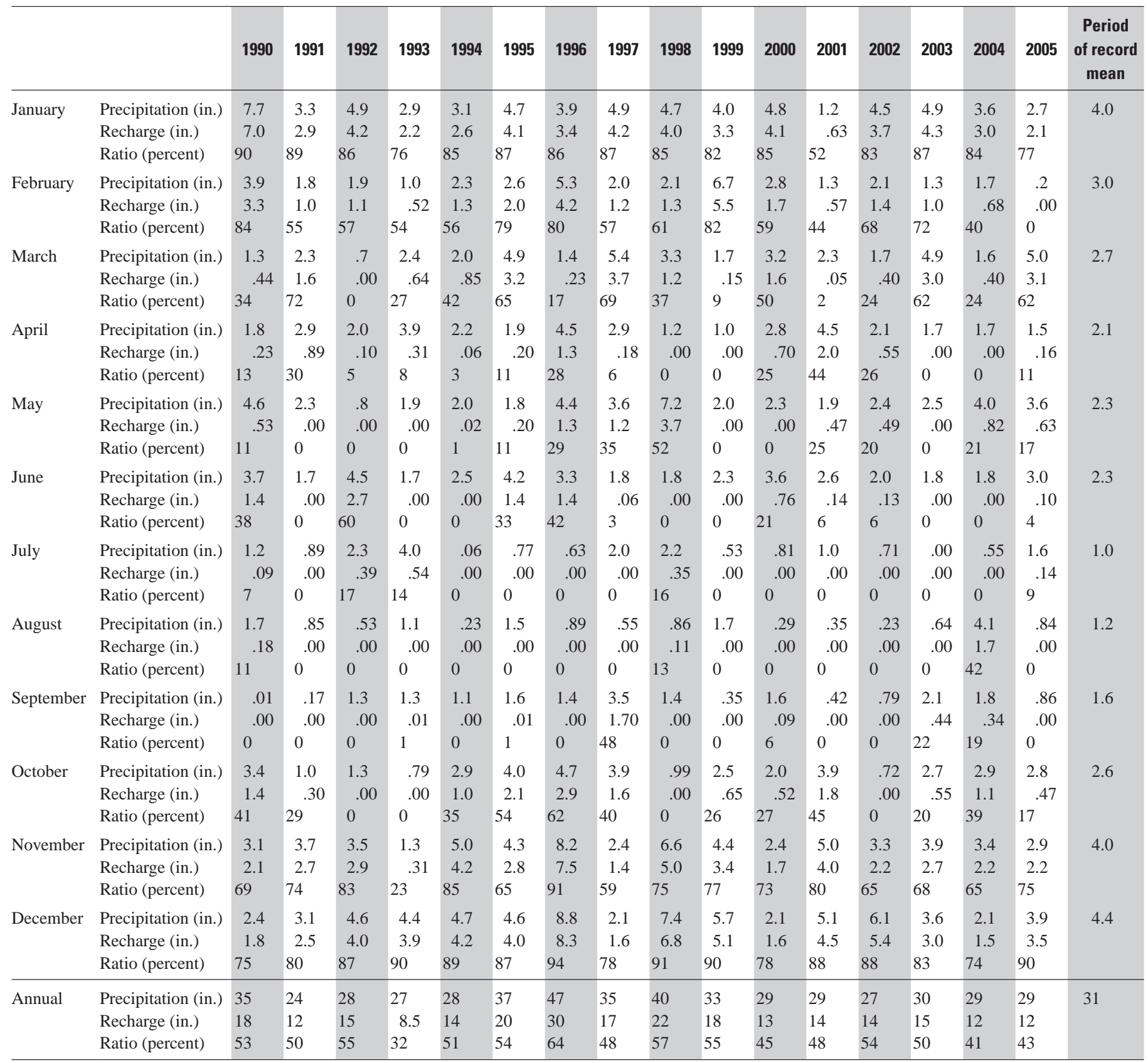


Table 15. Monthly precipitation and dual-coefficient FAO Penman-Monteith recharge using daily values, 1995-2005, Sandpoint Experiment Station, Idaho.

[Western Regional Climate Center (2006a, 2006b), U.S. Department of Commerce (2006). Mean precipitation values are through December 31 , 2005. A bbreviations: in., inch; ratio, recharge to precipitation ratio]

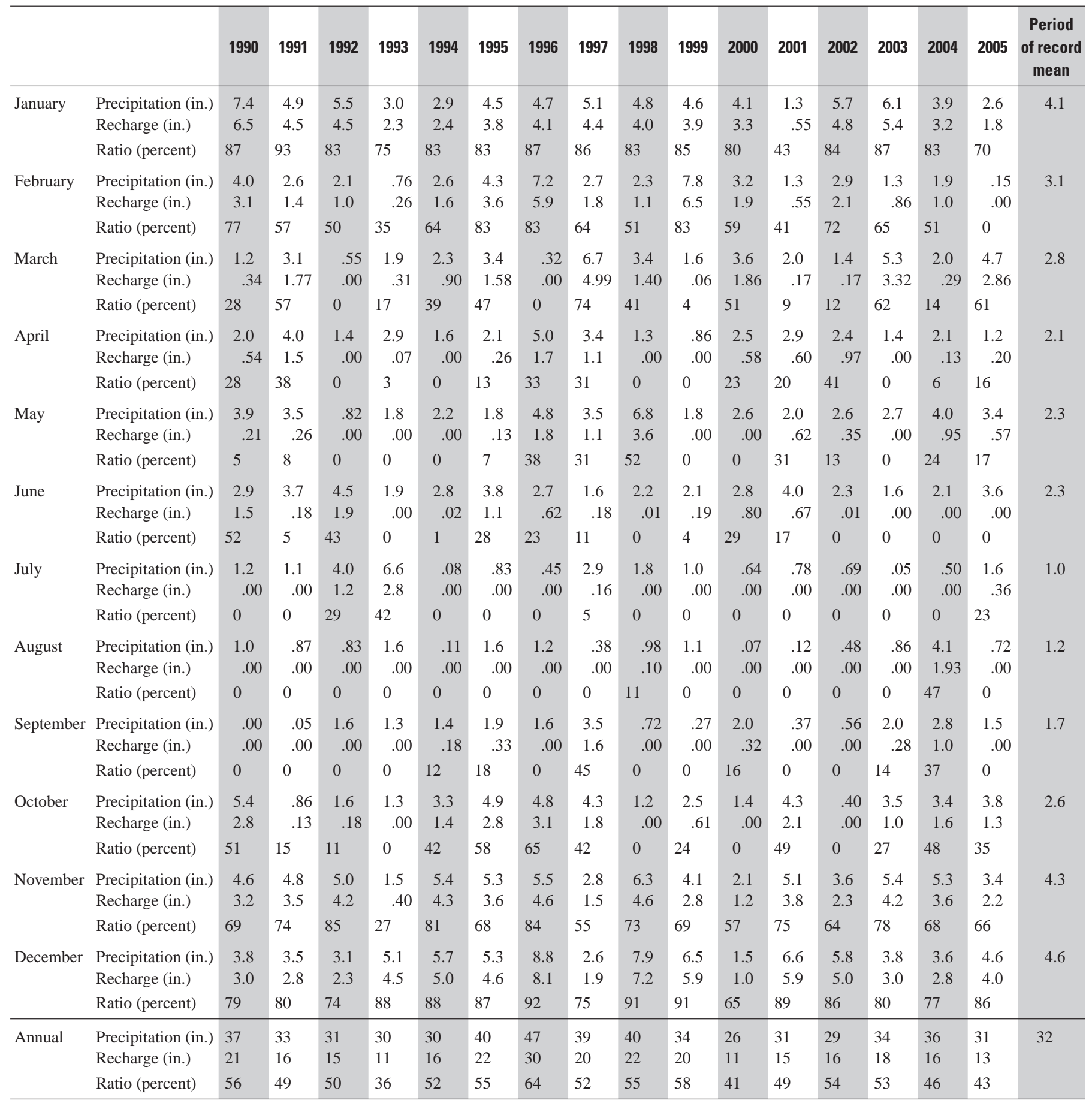



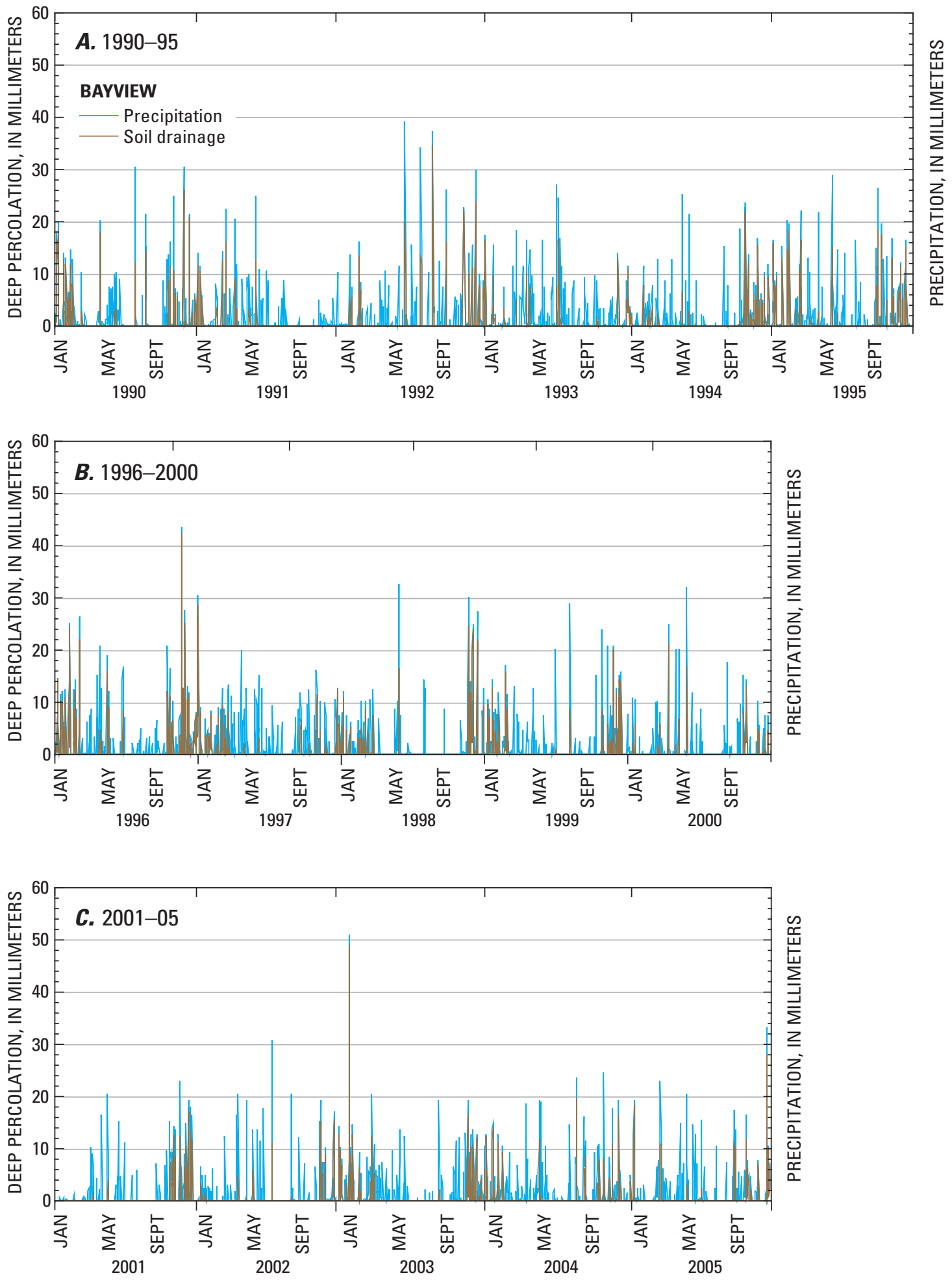

Figure 5. Daily values of precipitation and dual-coefficient FAO Penman-Monteith deep percolation, 1990-2005, Bayview Model Basin, Idaho. 

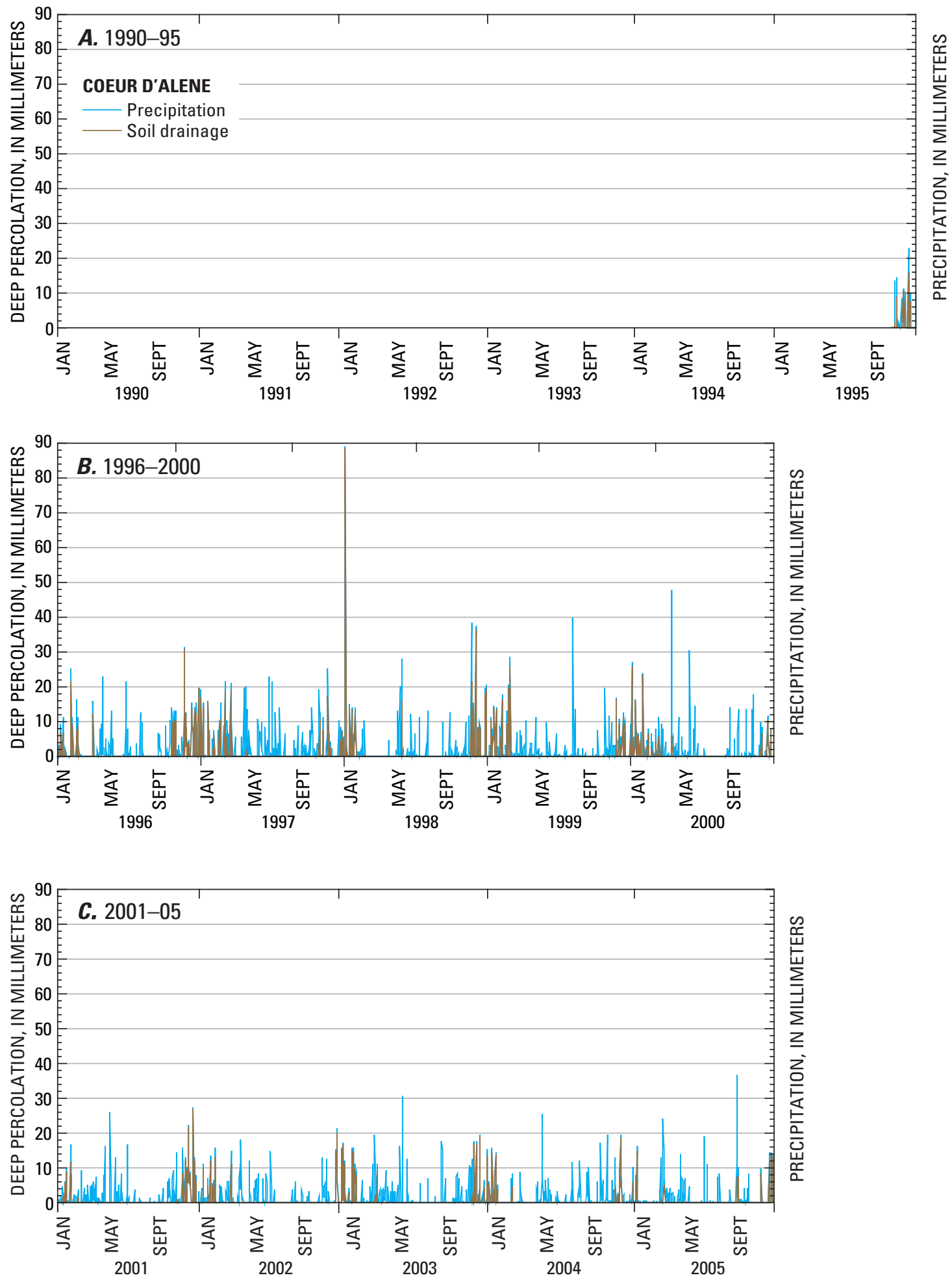

Figure 6. Daily values of precipitation and dual-coefficient FAO Penman-Monteith deep percolation, 1995-2005, Coeur D'Alene 1E, Idaho. 

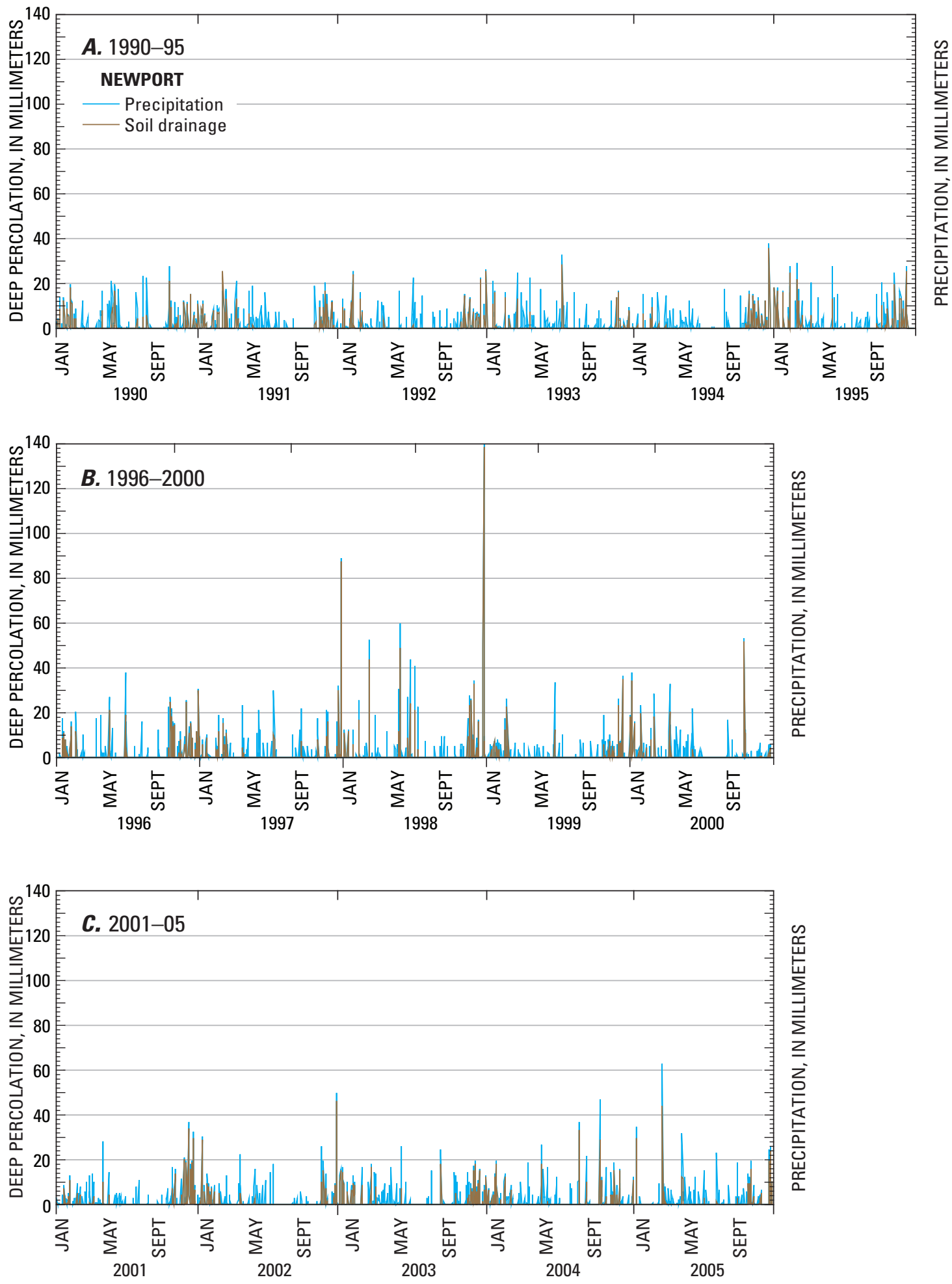

Figure 7. Daily values of precipitation and dual-coefficient FAO Penman-Monteith deep percolation, 1990-2005, Newport, Washington. 

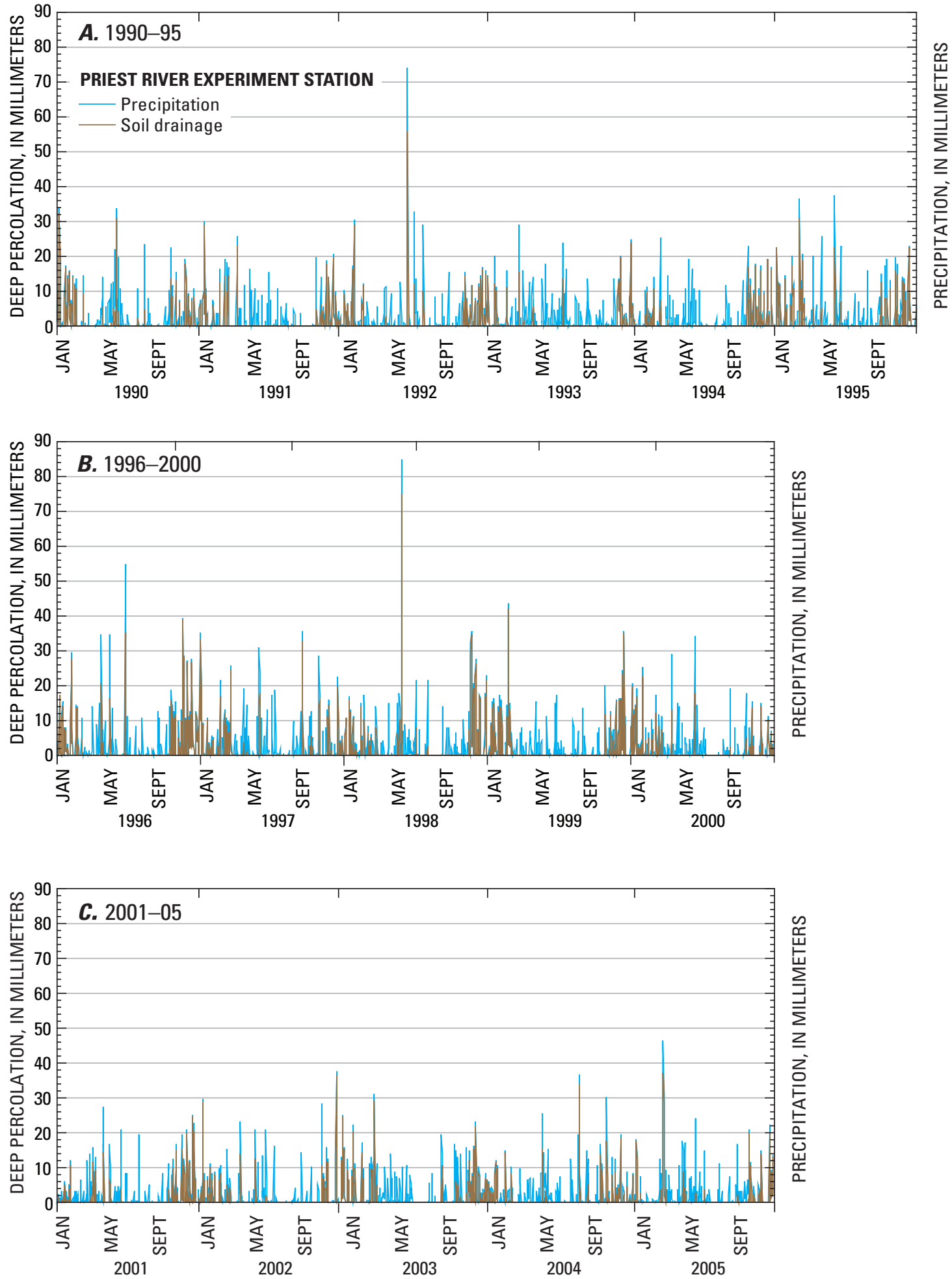

Figure 8. Daily values of precipitation and dual-coefficient FAO Penman-Monteith deep percolation, 1990-2005, Priest River Experiment Station, Idaho. 

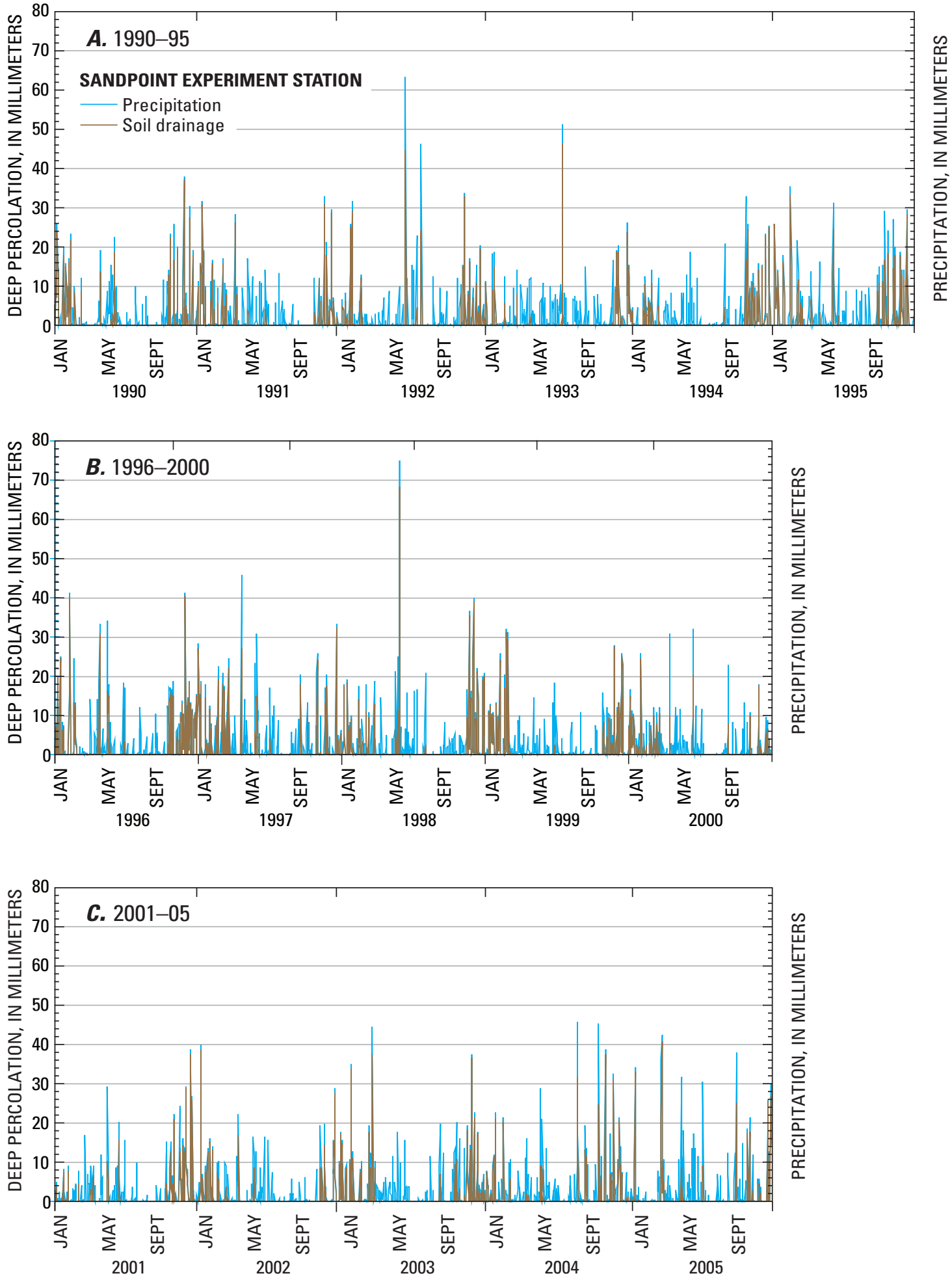

Figure 9. Daily values of precipitation and dual-coefficient FAO Penman-Monteith deep percolation, 1990-2005, Sandpoint Experiment Station, Idaho. 
The "Previous Work" section of this paper discusses earlier estimates of areal recharge and figure 10 shows a comparison between these monthly recharge rates and monthly recharge rates calculated in this study. The ranges of 1995-2005 monthly values of dual-coefficient FAO PenmanMonteith recharge are similar to those of the transient model of Bolke and Vaccaro (1988), though the ranges are larger than that of Buchanan (2000). If one considers the location and extent of these previous models and compares the Bolke and Vaccaro (1988) and the Golder Associates, Inc. (2004) recharge values to calculated recharge for Spokane WSO Airport, there is good agreement between the estimates. Similarly, if the recharge estimates from the three stations in the study area are compared to Buchanan's (2000) estimates, they fall within his range.

Although beyond the scope of this report, these recharge estimates for individual points need to be applied to the study area as a whole. A number of techniques may be appropriate for this task.

Areal recharge commonly is the most uncertain component of water budgets and ground-water flow models and is therefore usually calculated as the residual of other components. Without a priori knowledge of probable values, choosing between values of areal recharge calculated by different methods is difficult. Thus, the larger context provided by water budgets and ground-water flow model calibration is crucial in determining reasonable values.

\section{Summary and Conclusions}

The Spokane Valley-Rathdrum Prairie (SVRP) aquifer, which straddles the Idaho-Washington state line northeast of the City of Spokane, is the sole source of drinking water for more than 400,000 people. The area is experiencing rapid population growth, and a better understanding of the characteristics of the aquifer and its interaction with the Spokane River is necessary to guide the development and management of the resource. To this end, a multi-year study started in 2003 to gather data and construct a ground-water flow model of the SVRP aquifer that both states can use to evaluate water-management decisions.

Currently (2007), a ground-water-flow model that simulates ground-water/surface-water interaction is under construction by a joint team from the Idaho Department of Water Resources, University of Idaho, Washington State University, and the U.S. Geological Survey. This model requires values for areally-distributed recharge from precipitation, however, such values commonly are the most uncertain components of water budgets and ground-water flow models because it is virtually impossible to measure recharge over large areas. In previous flow models of the SVRP aquifer, various approaches or techniques were used to estimate areal recharge, ranging from assigning a uniform recharge to the entire model domain to calculating evapotranspiration for each model cell.

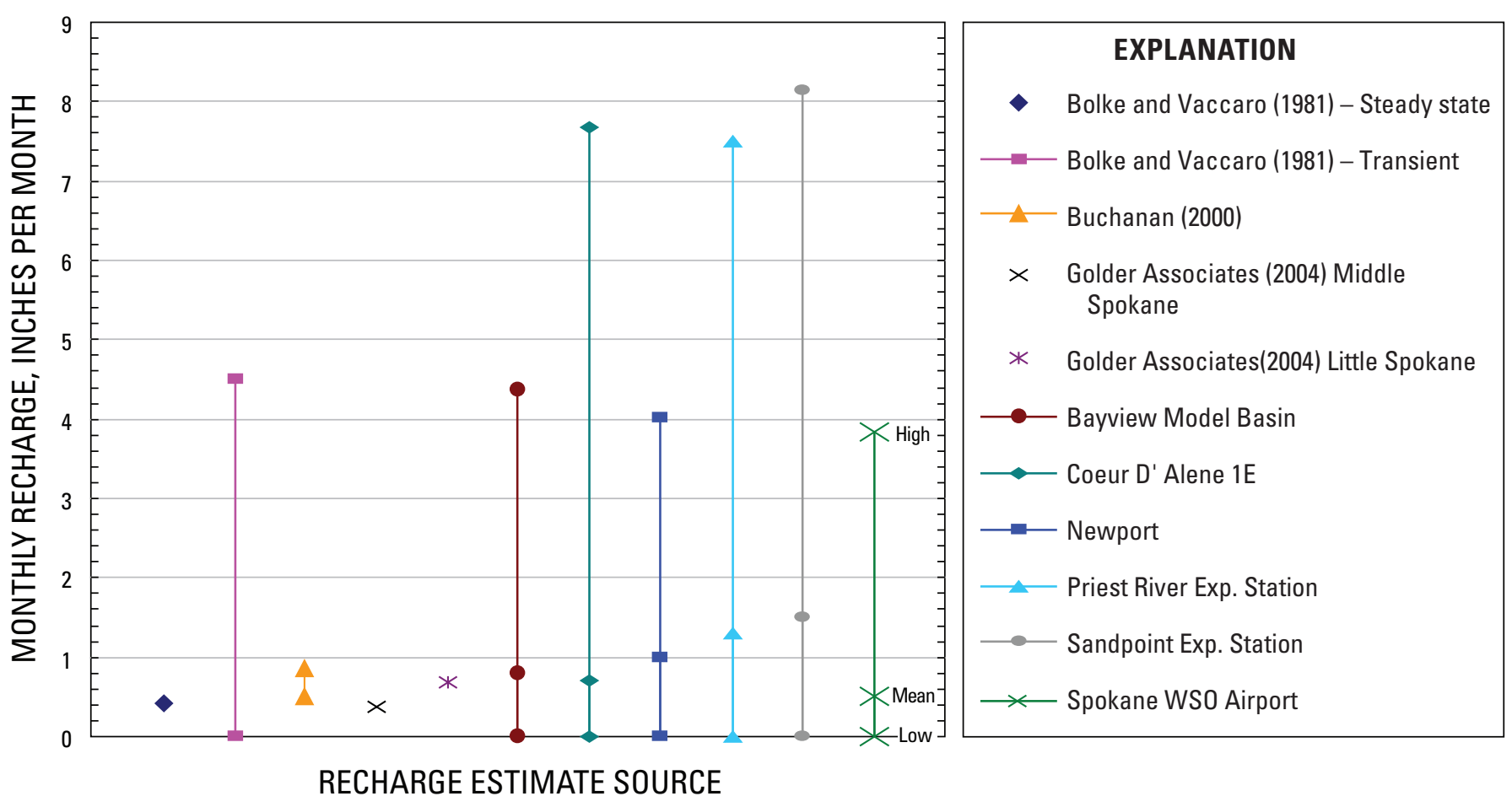

Figure 10. Comparison of previous monthly recharge rate estimates with dual-coefficient FAO Penman-Monteith recharge, 1995-2005. 
The National Weather Service has nine weather stations in or within 20 miles of the study area, although only six are active, and only three are within or adjacent to the SVRP study area. The data from these weather stations were used in the calculations of area recharge via several methods or approaches.

Four potential approaches were identified for determining areal recharge for the SVRP ground-water flow model:

1. A method (Langbein method) developed in which recharge is estimated on the basis of empirical data from other basins;

2. A method (USDA method) developed in which crop consumptive use and effective precipitation are first calculated and then subtracted from actual precipitation to yield an estimate of recharge;

3. An approach developed for the Eastern Snake Plain Aquifer Model (ESPAM) Enhancement Project in which recharge is calculated on the basis of precipitationrecharge relations from other basins; and

4. An approach in which reference evapotranspiration is calculated by the Food and Agriculture Organization (FAO) Penman-Monteith equation, crop consumptive use is determined (using a single or dual coefficient approach), and the amount of water which passes through the plant root zone (and thus becomes recharge) is calculated.

Mean annual recharge calculated with the Langbein method for the six active weather stations was 4 percent of mean annual precipitation, yielding the lowest mean annual values of the methods discussed in this report. The primary shortcoming of the Langbein method is that it can only be applied to annual time periods.

Mean monthly recharge calculated with the USDA method ranged from 53 to 73 percent of mean monthly precipitation. Mean annual recharge ranged from 64 to 69 percent of mean annual precipitation. Because the USDA effective rainfall equation was derived empirically using data from throughout the United States, it is difficult to evaluate how applicable the method is to the SVRP study area.

Mean monthly recharge calculations by the ESPAM method were made using thin-soil, thick-soil, and lava-rock parameters. The lava-rock parameters yielded the highest recharge values and the thick-soil parameters the lowest. For thin-soil parameters, calculated monthly recharge ranged from 10 to 29 percent of monthly mean precipitation and annual recharge ranged from 16 to 23 percent of mean annual precipitation. For thick-soil parameters, calculated monthly recharge ranged from 1 to 5 percent of monthly mean precipitation and annual recharge ranged from 2 to 4 percent of mean annual precipitation. For lava-rock parameters, calculated monthly recharge ranged from 37 to 57 percent of monthly mean precipitation and annual recharge ranged from 45 to 52 percent of mean annual precipitation. Because the ESPAM method equations were derived from previous work on the ESRP, for a given precipitation $(P)$, paired slope parameter $(K)$, and coefficient for curvature $(N)$, recharge calculated by the ESPAM method will be equivalent to that calculated for the ESRP.

Single-coefficient FAO Penman-Monteith mean monthly recharge values were calculated for the Spokane WSO Airport station: grass-referenced values of mean monthly recharge ranged from 0 to 81 percent of mean monthly precipitation and mean annual recharge was 21 percent of mean annual precipitation; alfalfa-referenced values of mean monthly recharge ranged from 0 to 85 percent of mean monthly precipitation and mean annual recharge was 24 percent of mean annual precipitation. The single-coefficient FAO Penman-Monteith equations used with mean monthly values yield mean monthly recharge values of zero during the eight warmest and driest months of the year (March-October). Such a result seems unlikely based on ground-water levels.

For all stations the lava-rock parameters yield the highest values of mean monthly recharge and the thick-soil parameters the lowest among the ESPAM techniques. USDA mean monthly recharge values are higher than any ESPAM values for all months. For the Spokane WSO Airport station, the single-coefficient FAO Penman-Monteith mean monthly recharge values are highest in the winter and lowest during the growing season.

The dual-coefficient FAO Penman-Monteith dual-crop evapotranspiration $\left(E T_{c d}\right)$ and deep percolation calculations were applied to daily values from the Spokane WSO Airport for January 1990 through December 2005. The resultant monthly totals show a temporal variability lacking in the single-coefficient mean monthly values and demonstrate that the daily amount and timing of precipitation dramatically affect calculated recharge. For the remaining five weather stations, 1990-2005 daily recharge was calculated using wind speed from the Spokane WSO Airport station and assuming that dewpoint was equal to the daily minimum temperature. For all six weather stations dual-coefficient FAO PenmanMonteith monthly recharge ranged from 0 to 94 percent of monthly precipitation.

Because areal recharge is often the most uncertain component of water budgets and ground-water flow models, it is often calculated as the residual of other components. Without a priori knowledge of probable values of areal recharge, choosing between values of recharge calculated by different methods is a challenging decision. Thus, the larger context provided by water budgets and ground-water flow model calibration is crucial in determining reasonable values. 


\section{Acknowledgments}

The author would like to thank B.A. Contor, Idaho State University, and G.S. Johnson, University of Idaho, for extensive technical discussions and suggestions during the preparation of this report. Technical suggestions were made by other members of the SVRP aquifer modeling team: M.E. Barber, Washington State University; M.A. Hossain, Washington State University; P.A. Hsieh, U.S. Geological Survey; J.L. Jones, U.S. Geological Survey; and A.H. Wylie, Idaho Department of Water Resources. Helpful reviews were provided by B.A. Contor, P.A. Hsieh, A.H. Wylie, and K.D. Peter.

\section{References Cited}

Allen, R.G., and Brockaway, C.E., 1983, Estimating consumptive irrigation requirements for crops in Idaho: Moscow, Idaho Water and Energy Resources Research Institute, University of Idaho, 183 p. Available online at http://www.idwr.idaho.gov/hydrologic/info/pubs/misc/Est Consumptive Use 08-1983.pdf

Allen, R.G., Pereira, L.S., Raes, D., and Smith, M., 1998, Crop evapotranspiration: Guidelines for computing crop water requirements: Rome, United Nations Food and Agriculture Organization, FAO Irrigation and Drainage Paper 56, 300 p. Available online at URL: http://www.fao. org/docrep/X0490E/X0490E00.htm. Errata sheet available online at URL: http://www.kimberly.uidaho.edu/water/ fao56/index.html

Blaney, H.F., and Criddle, W.D., 1962, Determining consumptive use and irrigation water requirements: U.S. Department of Agriculture, Agricultural Research Service Technical Bulletin 1275, 59 p.

Bolke, E.L., and Vaccaro, J.J., 1981, Digital-model simulation of the hydrologic flow system, with emphasis on ground water, in the Spokane Valley, Washington and Idaho: U.S. Geological Survey Open-File Report 80-1300, 43 p. Available online at URL: http://pubs.er.usgs.gov/usgspubs/ ofr/ofr801300

Buchanan, J.P., 2000, Unified groundwater flow model of the Rathdrum Prairie-Spokane Valley aquifer system: Prepared for Water Quality Management Program, Spokane County Public Works and Idaho Division of Environmental Quality: Cheney, Eastern Washington University, 23 p.
Bureau of Reclamation, 2006, AgriMet-The Pacific Northwest Cooperative Agricultural Weather Network-AgriMet network map: accessed Nov. 14, 2006, at URL: http://www. usbr.gov/pn/agrimet/agrimetmap/agrimap.html

CH2M HILL, 1998, City of Spokane wellhead protection program phase I-technical assessment report, for the city of Spokane, variously paginated.

Chapman, S.L., and Young, N.C., 1972, Water resources of western Oneida and southern Power Counties, Idaho: Boise, Idaho Department of Water Administration, Water Information Bulletin No. 25, 69 p. Available online at URL: http://www.idwr.idaho.gov/hydrologic/info/pubs/wib/ wib25-w-oneida s-power counties.pdf

Contor, B.A., 2004, Recharge on non-irrigated lands: Idaho Falls, University of Idaho, Idaho Water Resource Research Institute Technical Report 04-006, 19 p. Available online at URL: http://www.if.uidaho.edu/\%7ejohnson/DDW003 NIR $09 \quad 1 \quad 04 . p d f$

Cosgrove, D.M., Contor, B.A., and Johnson, G.A., 2006, Enhanced Snake Plain Aquifer Model final report: Moscow, University of Idaho Water Resources Research Institute Technical Report 06-002, 120 p., 26 tables, 2 appendixes. Available online at URL: http://www.if.uidaho.edu/ \%7ejohnson/FinalReport ESPAM1 1.pdf

Critchfield, H.J., 1983, General climatology, 4th ed: New York, Prentice Hall, 453 p.

Daly, Christopher, Neilson, R.P., and Phillips, D.L., 1994, A statistical-topographic model for mapping climatological precipitation over mountainous terrain: Journal of Applied Meteorology, v. 33, p. 140-158. Available online at URL: http://www.ocs.orst.edu/pub/prism/docs/jappclim94modeling mountain precip-daly.pdf

Daly, Christopher, Taylor, G.H., and Gibson, W.P., 1997, The PRISM approach to mapping precipitation and temperature: Reprints, 10th Conference on Applied Climatology, Reno, Nevada, American Meteorological Society, p. 10-12. Available online at URL: http://www.ocs.orst.edu/pub/ prism/docs/appclim97-prismapproach-daly.pdf

Daly, Christopher, and Taylor, G.H., with the Oregon Climate Service, 1998, 1961-90 mean monthly precipitation maps for the conterminous United States: PRISM Group, Oregon State University. Available online at URL: http://www.ocs. orst.edu/prism/state products/maps.phtml?id=NM

DHI software, 2006, MIKE SHE: accessed November 14, 2006, at http://www.dhisoftware.com/mikeshe/ 
Doorenboos J., and Pruitt, W.O., 1977, Guidelines for predicting crop water requirements: Rome, United Nations, Food and Agriculture Organization, FAO Irrigation and Drainage Paper 24, 179 p.

Fenneman, N.M., 1931, Physiography of Western United States: New York, McGraw-Hill, 534 p., 1 pl. in pocket.

Garabedian, S.P., 1992, Hydrology and digital simulation of the regional aquifer system, Eastern Snake River plain, Idaho: U.S. Geological Survey Professional Paper 1408-F, 102 p., 10 pls. in pocket. Available online at URL: $\underline{\text { http:// }}$ pubs.er.usgs.gov/usgspubs/pp/pp1408F

Godfrey, Bruce, 2000, Köppen climate classification for the conterminous United States: accessed November 14, 2006, at http://snow.ag.uidaho.edu/Clim Map/koppen.htm.

Golder Associates, Inc., 2004, Report to WRIA 55 and 57 planning unit on level 2 technical assessment watershed simulation model: Seattle, Golder Associates, Inc., prepared under grant no. 9800300 from the Washington Department of Ecology, February 14, 2004, 51 p., plus bibliography, figures, tables, 4 appendices.

Kafri, U., and Ben-Asher, J., 1978, Computer estimates of natural recharge through soils in southern Arizona, U.S.A.: Journal of Hydrology, v. 38, no. 1-2, p. 125-138.

Kahle, S.C., Caldwell, R.R., and Bartolino, J.R., 2005, Compilation of geologic, hydrologic, and ground-water flow modeling information for the Spokane ValleyRathdrum Prairie Aquifer, Spokane County, Washington, and Bonner and Kootenai Counties, Idaho: U.S. Geological Survey Scientific Investigations Report 2005-5227, 64 p., 1 pl. in pocket. Available online at URL: http://pubs.er.usgs. gov/usgspubs/sir/sir20055227

Langbein, W.B., 1961, Simplified method of estimation, in Nace, R.L., and others, 1961, Water resources of the Raft River basin, Idaho-Utah: U.S. Geological Survey WaterSupply Paper 1587, p. 36-47. Available online at URL: http://pubs.er.usgs.gov/pubs/wsp/wsp1587

Langbein, W.B., and others, 1949, Annual runoff in the United States: U.S. Geological Survey Circular 52, 14 p. Available online at URL: http://pubs.er.usgs.gov/pubs/cir/cir52

Mundorff, M.J., Crosthwaite, E.G., and Kilburn, Chabot, 1964, Ground water for irrigation in the Snake River basin in Idaho: U.S. Geological Survey Water-Supply Paper 1654, 224 p., 6 pls. in pocket. Available online at URL: http:// pubs.er.usgs.gov/usgspubs/wsp/wsp1654
Natural Resources Conservation Service, 2006a, Soil Survey Geographic (SSURGO) database for Bonner County area, Idaho, Parts of Bonner and Boundary Counties: Natural Resources Conservation Service, United States Department of Agriculture, accessed November 14, 2006, at http:// soildatamart.nrcs.usda.gov/

Natural Resources Conservation Service, 2006b, Soil Survey Geographic (SSURGO) database for Kootenai County area, Idaho: Natural Resources Conservation Service, United States Department of Agriculture, accessed November 14, 2006, at http://soildatamart.nrcs.usda.gov/

Natural Resources Conservation Service, 2006c, Soil Survey Geographic (SSURGO) database for Spokane County, Washington: Natural Resources Conservation Service, United States Department of Agriculture, accessed November 14, 2006, at http://soildatamart.nrcs.usda.gov/

Olness, I.A., 1993, Formulation of a finite-difference groundwater flow model for the Spokane Valley aquifer, Washington: Cheney, Eastern Washington University, M.S. thesis, $101 \mathrm{p}$.

Rich, L.R., 1951, Consumptive use of water by forest and range vegetation: Proceedings-American Society of Civil Engineers, v. 77, separate no. 90, 14 p.

Rich, L.R., 1952, Forest and range vegetation: American Society of Civil Engineers Transactions, v. 117, p. 974-989. [Republication of paper above.]

Soil Survey Staff, 2006a, State Soil Geographic (STATSGO) Database for Idaho: Natural Resources Conservation Service, United States Department of Agriculture, accessed November 14, 2006, at http://www.ncgc.nrcs.usda.gov/ products/datasets/statsgo/index.html

Soil Survey Staff, 2006b, State Soil Geographic (STATSGO) Database for Washington: Natural Resources Conservation Service, United States Department of Agriculture, accessed November 14, 2006, at http://www.ncgc.nrcs.usda.gov/ products/datasets/statsgo/index.html

Tindall, J.A., Kunkell, J.R., and Anderson, D.E., 1999, Unsaturated zone hydrology for scientists and engineers: Upper Saddle River, N.J., Prentice Hall, 624 p.

U.S. Department of Agriculture, 1970, Irrigation water requirements (rev. 2): Soil Conservation Service, Engineering Division, Technical Release No. 21, 88 p. 
U.S. Department of Commerce, 2005, 2005 Local climatological data-annual summary with comparative data-Spokane Washington (GEG): U.S. Department of Commerce, ISSN 0198-5485, 8 p. Available online at URL: http://www7.ncdc.noaa.gov/IPS/LCDPubs?action=getpubl ication

U.S. Department of Commerce, 2006, National Climatic Data Center: accessed November 14, 2006, at http://www.ncdc. noaa.gov.

Weisel, C.J., 1981, Soil survey of Kootenai County area, Idaho: U.S. Department of Agriculture, Soil Conservation Service, $255 \mathrm{p}$.
Western Regional Climate Center, 2006a, Idaho climate summaries: accessed November 14, 2006, at http://www. wrcc.dri.edu/summary/climsmid.html

Western Regional Climate Center, 2006b, Washington climate summaries: accessed November 14, 2006, at http://www. wrcc.dri.edu/summary/climsmwa.html

Wright, J.L, 1993, Nongrowing season ET from irrigated fields, in Allen, R.G., and Neale, C.M.U., eds., Management of irrigation and drainage systems: Integrated perspectives: American Society of Civil Engineers Irrigation and Drainage Division, Conference proceedings, Park City, Utah, 21-23 July, 1993, p. 1005-1014. 


\section{Appendix A. Soils}

Nearly all of the Spokane Valley-Rathdrum Prairie aquifer is overlain by two STATSGO soil mapping units: the Kootenai-Bonner-Rathdrum unit mostly north of Rathdrum and near Hayden Lake and the Garrison-Avonville-Marble Variant unit in most of the remainder of the study area (fig. A1; Soil Survey Staff, 2006a, b). Virtually all the soil series comprising these mapping units are classified in hydrologic soil groups A and B (rated on a scale from A to D, ranging from high values of saturated hydraulic conductivity and deep free-water occurrence, (A), to moderately low saturated hydraulic conductivity and shallow free-water occurrence, (D), (Weisel, 1981)). Thus, precipitation may be expected to pass readily into the root zone and beyond. Measured mean vertical permeability ranges from 1.3 to greater than 40 feet per day for both units. Golder Associates, Inc. (2004) reported that during calibration of their integrated ground-water/surface-water model of the Middle Spokane watershed, a uniform change of all soils in the model to type D (thus decreasing vertical hydraulic conductivity by approximately four orders of magnitude) decreased mean weekly recharge by about 50 percent.

By way of comparison, Garabedian's (1992) ESRP thin soil infiltration rate group contained hydrologic soil groups A$\mathrm{D}$, but were primarily of groups A and B. His thick soil group contained hydrologic soil groups B-D, but were primarily of groups B and C.

Contor (2004) assumed that the rangeland plants of the ESRP had root systems developed throughout the entire soil profile. Because water in the root zone is available for evapotranspiration, the increased time necessary for water to pass through a thick soil results in less recharge than for a thin soil with the same hydrologic properties. Because most of the series comprising the two STATSGO mapping units in the study area are described as "very deep," no effort was made in the current report to differentiate soil depths.

Available water capacity values for the soil mapping units range from 0.01 to $0.6 \mathrm{in} / \mathrm{in}(10-600 \mathrm{~mm} / \mathrm{m}$ ) (Natural Resources Conservation Service, 2006a, 2006b, 2006c).

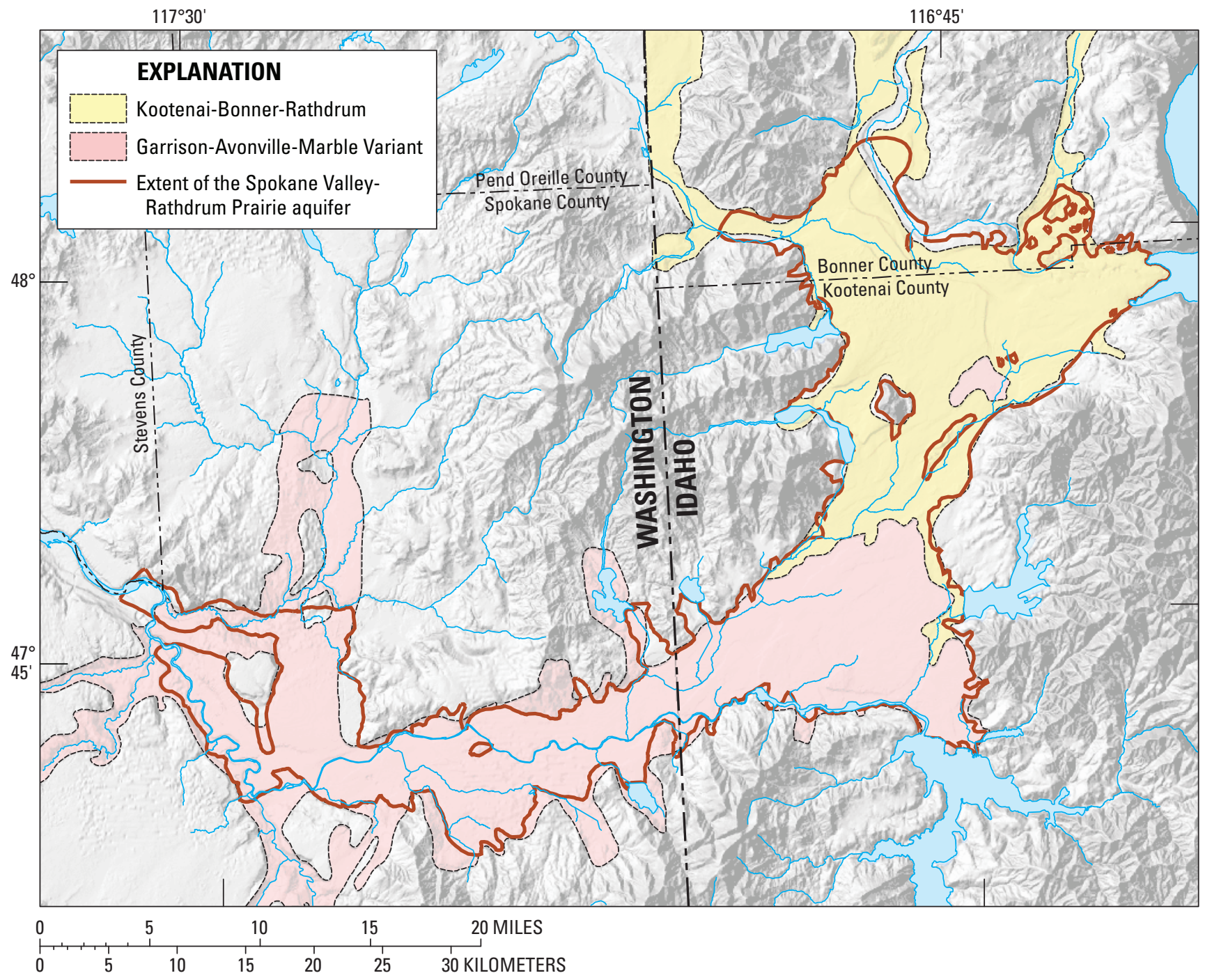

Figure A1. Major soil mapping units in the study area. 
This page intentionally left blank. 
Manuscript approved for publication, March 13, 2007

Prepared by the USGS Publishing Network,

Publishing Service Center, Tacoma, Washington

Bill Gibbs

Bob Crist

Debra Grillo

Bobbie Jo Richey

Chester Zenone

For more information concerning the research in this report, contact the Idaho Water Science Center Director,

230 Collins Road

Boise, Idaho 83702-4520

http://id.water.usgs.gov 
